\title{
Anxiety-Like Behavior of Prenatally Stressed Rats Is Associated with a Selective Reduction of Glutamate Release in the Ventral Hippocampus
}

\author{
Jordan Marrocco, ${ }^{1}$ Jérôme Mairesse, ${ }^{1}$ Richard Teke Ngomba, ${ }^{2}$ Viviana Silletti, ${ }^{1}$ Gilles Van Camp,${ }^{1}$ \\ Hammou Bouwalerh, ${ }^{1}$ Maria Summa, ${ }^{3}$ Anna Pittaluga, ${ }^{3}$ Ferdinando Nicoletti, ${ }^{2,4}$ Stefania Maccari, ${ }^{1}$ \\ and Sara Morley-Fletcher ${ }^{1}$ \\ ${ }^{1}$ Neural Plasticity Team-UMR CNRS/USTL 8576 Structural and Functional Glycobiology Unit, North University of Lille, 59655 Villeneuve d'Ascq France, \\ 2IRCCS Neuromed, 86077 Pozzilli, Italy, ${ }^{3}$ Department of Experimental Medicine, University of Genoa, 16126 Genoa, Italy, and ${ }^{4}$ Department of \\ Pharmacology, Sapienza University of Rome, 00185 Rome, Italy
}

\begin{abstract}
Abnormalities of synaptic transmission and plasticity in the hippocampus represent an integral part of the altered programming triggered by early life stress. Prenatally restraint stressed (PRS) rats develop long-lasting biochemical and behavioral changes, which are the expression of an anxious/depressive-like phenotype. We report here that PRS rats showed a selective impairment of depolarization- or kainate-stimulated glutamate and $\left[{ }^{3} \mathrm{H}\right] \mathrm{D}$-aspartate release in the ventral hippocampus, a region encoding memories related to stress and emotions. GABA release was unaffected in PRS rats. As a consequence of reduced glutamate release, PRS rats were also highly resistant to kainate-induced seizures. Abnormalities of glutamate release were associated with large reductions in the levels of synaptic vesiclerelated proteins, such as VAMP (synaptobrevin), syntaxin-1, synaptophysin, synapsin Ia/b and IIa, munc-18, and Rab3A in the ventral hippocampus of PRS rats. Anxiety-like behavior in male PRS (and control) rats was inversely related to the extent of depolarizationevoked glutamate release in the ventral hippocampus. A causal relationship between anxiety-like behavior and reduction in glutamate release was demonstrated using a mixture of the mGlu2/3 receptor antagonist, LY341495, and the GABA $\mathrm{B}_{\mathrm{B}}$ receptor antagonist, $\mathrm{CGP} 52432$, which was shown to amplify depolarization-evoked $\left[{ }^{3} \mathrm{H}\right] \mathrm{D}$-aspartate release in the ventral hippocampus. Bilateral microinfusion of CGP52432 plus LY341495 in the ventral hippocampus abolished anxiety-like behavior in PRS rats. These findings indicate that an impairment of glutamate release in the ventral hippocampus is a key component of the neuroplastic program induced by PRS, and that strategies aimed at enhancing glutamate release in the ventral hippocampus correct the "anxious phenotype" caused by early life stress.
\end{abstract}

\section{Introduction}

The effects of stress on the brain have long been associated with the onset and exacerbation of several neuropsychiatric disorders such as depression, anxiety, drug addiction, and epilepsy (McEwen, 2012). Alterations in glutamate neurotransmission are believed to play a role in the pathophysiology of such disorders (Ongür, 2008; Chen et al., 2010). Exposure to stress and treatment with glucocorticoids alter glutamatergic neurotransmission and neuroplasticity in brain regions related to depression

Received March 2, 2012; revised Sept. 26, 2012; accepted 0ct. 1, 2012.

Author contributions: F.N., S.M., and S.M.-F. designed research; J. Marrocco, J. Mairesse, R.T.N., V.S., G.V.C., M.S., A.P., and S.M.-F. performed research; J. Marrocco, J. Mairesse, G.V.C., H.B., and S.M.-F. analyzed data; J. Marrocco, J. Mairesse, R.T.N., F.N., S.M., and S.M.-F. wrote the paper.

This study was supported by North University of Lille-Lille1 and the Sapienza University of Rome (Frame Agreement signed between the two universities on 15/02/2007) and by (entre National de la Recherche Scientifique in the framework of the European Research Team (GDRE 691) "Early Programming of Modern Diseases" (Coordinators S. Maccari and Dr. A. Moles). J. Marrocco was supported by the Ministry of French Education. J. Mairesse received funding from Fondation Recherche Médicale.

The authors declare no competing financial interests.

Correspondence should be addressed to Dr. Sara Morley-Fletcher, North University of Lille, France, Neuroplasticity Team-CNRS UMR 8576/ UGSF, Structural and Functional Glycobiology Unit, Bât C9, Avenue Mendeleiev, 59655 Villeneuve d'Ascq France. E-mail: sara.morley-fletcher@univ-lille1.fr.

DOI:10.1523/JNEUROSCI.1040-12.2012

Copyright $\odot 2012$ the authors $\quad 0270-6474 / 12 / 3217143-12 \$ 15.00 / 0$ and anxiety, such as the hippocampus, amygdala, and prefrontal cortex (Mozhui et al., 2010; reviewed by Popoli et al., 2012). Musazzi et al. (2010) have shown that acute stress led to an accumulation of presynaptic SNARE complexes in cortical synaptic membranes, thus raising the interesting possibility that stress directly affects the presynaptic machinery of glutamate release. The study of glutamate release in response to chronic stress is still at its infancy (Moghaddam, 2002; Yamamoto and Reagan, 2006), and there are no data on how early life stress affects glutamate release in the adult life. The latter issue is particularly relevant because early life stress causes long-lasting changes in neuroplasticity that result in an increased vulnerability to stress-related disorders in adult life (Meaney et al., 2007; Darnaudéry and Maccari, 2008; Lupien et al., 2009). Prenatal restraint stressed (PRS) rats represent a model that recapitulates some of the features of depression and anxiety (Maccari et al., 1995; Dugovic et al., 1999; Darnaudéry et al., 2006; Maccari and Morley-Fletcher, 2007; Zuena et al., 2008; Van Waes et al., 2009; Laloux et al., 2012; Mairesse et al., 2012a). Interestingly, male PRS rats show a prominent anxiouslike phenotype, whereas female PRS rats are more prone to develop a depressive-like phenotype (Zuena et al., 2008; MorleyFletcher et al., 2011; Van Waes et al., 2011). PRS rats show also a 
reduced number of proteins involved in signal transduction and neuroplasticity regulation as revealed by a recent mass spectrometry analysis (Mairesse et al., 2012b). Most of these changes are reversed by chronic antidepressant treatment (Morley-Fletcher et al., 2003, 2004, 2011; Mairesse et al., 2012a). Hence, PRS rats represent an animal model of stress-related disorders that meets the criterion of construct validity because it replicates environmental factors implicated in the etiology of depression and anxiety (Krishnan and Nestler, 2008, 2010). In addition, most of the abnormalities in synaptic transmission and plasticity in the hippocampus of PRS rats are seen in the ventral hippocampus (Zuena et al., 2008; Morley-Fletcher et al., 2011), the specific portion of the hippocampus that encodes memories related to stress and emotions (Fanselow and Dong, 2010). We report here that male PRS rats show a selective impairment of glutamate release in the ventral hippocampus associated with anxiety and a reduced expression of the SNARE proteins and vesicle-associated proteins, as well as the mammalian uncoordinated-18 Munc-18, and the glutamate terminal-specific monomeric GTP-binding protein, Rab3a. Pharmacological enhancement of glutamate release in the ventral hippocampus corrected the anxious-like phenotype of PRS rats.

\section{Materials and Methods Animals}

Forty nulliparous female Sprague Dawley rats (20 for control and 20 for PRS groups), weighing $\sim 250 \mathrm{~g}$, were purchased from a commercial breeder (Charles River). Animals were housed at constant temperature $\left(22 \pm 2^{\circ} \mathrm{C}\right)$ and under a regular $12 \mathrm{~h} \mathrm{light/dark}$ cycle (lights on at 8.00 A.M.). Pregnant females were randomly assigned to stressed or control groups. ( $n=12$ per group).

\section{Stress protocol}

Animals were subjected to PRS according to our standard protocol (Maccari et al., 1995; Morley-Fletcher et al., 2003). From day 11 of pregnancy until delivery, pregnant female rats were subjected to three stress sessions daily (45 min each), during which they were placed in transparent plastic cylinders and exposed to bright light. Only male offspring from litters containing 10-14 pups with a comparable number of males and females were used for the experiments. A maximum of one or two male pups were taken from each litter for each measure to remove any litter effects (Becker and Kowall, 1977; Chapman and Stern, 1979). All experiments followed the rules of the European Communities Council Directive 86/ 609/EEC. The local ethical committee approved the prenatal stress procedure. We used the same sets of animals ( 3 month olds) for anxiety and glutamate release (see correlation); in microinfusion experiments we used the same sets of animals ( 3 month olds) for the two tests of anxiety. For the other experiments we used separate sets of animals (2 month olds).

\section{Assessment of glutamate and GABA release in superfused synaptosomal preparations}

Purified synaptosomes isolated from the ventral and the dorsal hippocampus (dissected as described by Robertson et al., 2005), the perirhinal cortex, the prefrontal cortex, the amygdala, and the striatum were prepared as described by Dunkley et al. (1986), with minor modifications. Briefly, the tissue was homogenized in 10 volumes of $0.32 \mathrm{M} \mathrm{su}-$ crose, buffered to $\mathrm{pH} 7.4$ with TRIS (final concentration $0.01 \mathrm{M}$ ) using a glass Teflon tissue grinder (clearance $0.25 \mathrm{~mm}$ ). The homogenate was centrifuged at $1000 \times g$ for $5 \mathrm{~min}$, to remove nuclei and debris; the supernatant was gently stratified on a discontinuous Percoll gradient (6, 10, and 20\% v/v in Tris-buffered sucrose) and centrifuged at 33,500 $\times g$ for $5 \mathrm{~min}$. The layer between 10 and 20\% Percoll (synaptosomal fraction) was collected and washed by centrifugation. The synaptosomal pellet was then resuspended in physiological medium (standard medium) with the following composition (in mM): $140 \mathrm{NaCl}, 3 \mathrm{KCl}, 1.2 \mathrm{MgSO}_{4}, 1.2 \mathrm{CaCl}_{2}$,
$1.2 \mathrm{NaH}_{2} \mathrm{PO}_{4}, 5 \mathrm{NaHCO}_{3}, 10$ mM HEPES, and 10 glucose, pH 7.2-7.4. Synaptosomal protein levels were determined according to Bradford (1976). Synaptosomes were incubated for $15 \mathrm{~min}$ a $37^{\circ} \mathrm{C}$ in a rotary water bath in the absence (experiments of endogenous glutamate and GABA release) or presence of $\left[2,3-{ }^{3} \mathrm{H}\right] \mathrm{D}$-aspartate $(20-50 \mathrm{~nm}$; sp. act. $11.3 \mathrm{Ci} /$ mmol, PerkinElmer).

Identical portions of the synaptosomal suspensions were layered on microporous filters at the bottom of parallel chambers in a Superfusion System (Raiteri and Raiteri 2000; Ugo Basile) maintained at $37^{\circ} \mathrm{C}$ and superfused at $0.5 \mathrm{ml} / \mathrm{min}$ with standard physiological solution.

When studying the release of neurotransmitter evoked by kainic acid (Tocris Bioscience) or depolarizing concentrations of $\mathrm{K}^{+}$, synaptosomes were transiently (90 s) exposed, at $t=39 \mathrm{~min}$, to $10 \mu \mathrm{m}$ kainic acid or to 20 (amygdala) or 12 (all other regions) $\mathrm{mm} \mathrm{K}^{+}$(substituted for $\mathrm{NaCl}$ in the superfusate). Superfusion was always performed with media containing $50 \mu \mathrm{M}$ amino-oxyacetic acid (Sigma) to inhibit GABA metabolism. Three superfusate fractions were collected according to the following scheme: two $3 \mathrm{~min}$ fractions (basal release), one before $(t=36-39 \mathrm{~min}$, b1) and one after $(t=45-48 \mathrm{~min}, \mathrm{~b} 3)$ a $6 \mathrm{~min}$ fraction $(t=39-45 \mathrm{~min}$; evoked release, b2). Fractions collected and superfused synaptosomes were counted for radioactivity or for endogenous amino acid content. Endogenous glutamate and GABA were measured by HPLC analysis after precolumn derivatization with $o$-phthalaldehyde and separation on a $\mathrm{C}_{18}$ reverse-phase chromatographic column $\left(10 \times 4.6 \mathrm{~mm}, 3 \mu \mathrm{m}\right.$; at $30^{\circ} \mathrm{C}$; Chrompack) coupled to a fluorimetric detector (excitation wavelength, $350 \mathrm{~nm}$; emission wavelength, $450 \mathrm{~nm}$ ). Buffers and the gradient program were as follows: solvent $\mathrm{A}, 0.1 \mathrm{M}$ sodium acetate, $\mathrm{pH}$ 5.8/methanol, 80:20; solvent B, 0.1 M sodium acetate, $\mathrm{pH}$ 5.8/methanol, 20:80; solvent C, 0.1 m sodium acetate, $\mathrm{pH}$ 6.0/methanol, 80:20; gradient program, $100 \% \mathrm{C}$ for $4 \mathrm{~min}$ from the initiation of the program; $90 \% \mathrm{~A}$ and $10 \% \mathrm{~B}$ in $1 \mathrm{~min}$; isocratic flow, $2 \mathrm{~min} ; 78 \% \mathrm{~A}$ and $22 \% \mathrm{~B}$ in $2 \mathrm{~min}$; isocratic flow, $6 \mathrm{~min} ; 66 \% \mathrm{~A}$ and $34 \% \mathrm{~B}$ in $3 \mathrm{~min} ; 42 \% \mathrm{~A}$ and $58 \% \mathrm{~B}$ in $1 \mathrm{~min} ; 100 \% \mathrm{~B}$

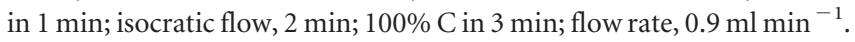
Homoserine was used as the internal standard. Synaptosomal protein contents were determined according to Bradford (1976). The amount of endogenous glutamate and GABA from synaptosomes in superfusate fractions was expressed as picomoles per milligram of protein (pmol $\mathrm{mg}^{-1}$ protein). Radioactivity in each superfusate fraction was quantified by liquid scintillation. The amount of radioactivity released into each superfusate fraction was expressed as a percentage of the total synaptosomal tritium content at the start of the fraction collected (fractional efflux). The depolarization-induced overflow was estimated by subtracting the neurotransmitter content into the first and the third fractions collected (basal release, b1 and b3) from that in the 6 min fraction collected during and after the depolarization pulse (evoked release, b2).

\section{Assessment of $\left[{ }^{3} \mathrm{H}\right] \mathrm{D}$-aspartate release in hippocampal slice preparations}

Slices (0.4 mm thick) from the dorsal or ventral hippocampus were prepared using a Mcllwain tissue chopper (Mickle Laboratory Engineering) and then placed in a superfusion medium with the following composition (in mM): $125 \mathrm{NaCl}, 3 \mathrm{KCl}, 1.2 \mathrm{MgSO}_{4}, 1.2 \mathrm{CaCl}_{2}, 1 \mathrm{NaH}_{2} \mathrm{PO}_{4}, 22$ $\mathrm{NaHCO}_{3}$, and 10 glucose (aeration with $95 \% \mathrm{O}_{2}$ and $5 \% \mathrm{CO}_{2}$ ), $\mathrm{pH}$ $7.2-7.4$, at $2-4^{\circ} \mathrm{C}$. Slices were rinsed by changing the physiological solution every $20 \mathrm{~min}$. Slices were labeled with $90 \mathrm{nM}\left[{ }^{3} \mathrm{H}\right]_{\mathrm{D}}$-aspartate $(20$ $\min$ at $37^{\circ} \mathrm{C}$ ) in standard medium in an atmosphere of $95 \% \mathrm{O}_{2}$ and $5 \%$ $\mathrm{CO}_{2}$. After washing with tracer-free medium, slices were transferred to parallel superfusion chambers (one slice/chamber) and superfused (1 $\mathrm{ml} / \mathrm{min}$ at $37^{\circ} \mathrm{C}$ ). After $60 \mathrm{~min}$ of superfusion to equilibrate the system, six 5 min samples were collected. Slices were exposed to $30 \mathrm{~mm} \mathrm{~K}^{+}$in the absence or presence of 3-[[(3,4-dichlorophenyl)methyl]amino]propyl] diethoxymethyl) phosphinic acid (CGP52432; Tocris Bioscience) and (2S)-2-amino-2-[(1S,2S)-2-carboxycycloprop-1-yl]-3-(xanth-9-yl) propanoic acid (LY341495; Tocris Bioscience) for $5 \mathrm{~min}$, starting from $t=70$ min of superfusion. Drugs were added from $t=30 \mathrm{~min}$ of superfusion until the end of the experiments. Samples collected and solubilized slices (Soluene; Canberra Packard) were counted for radioactivity. The amount of radioactivity released into each superfusate fraction was expressed as fractional efflux (see above). Drug effects were expressed as "induced overflow" and were 
estimated by subtracting the neurotransmitter content into the second and the fifth fractions collected from that in the third and in the fourth fractions collected.

\section{In vivo studies}

Kainate-induced motor seizures and electroencephalography/electromyography recording

We assessed kainate-induced limbic motor seizures in separate groups of control and PRS rats ( $n=6$ per group). Kainate-induced seizures represent an established experimental animal model of temporal lobe epilepsy in humans (Sharma et al., 2007; Joëls, 2009). Animals underwent 2 weeks of habituation to electroencephalogram (EEG)/electromyogram (EMG) recording before behavioral assessment for motor seizures. Rats were anesthetized with ketamine/xylazine (75/10 mg/kg, i.m.). Electrodes for EEG recordings were chronically implanted using a stereotaxic apparatus. Three stainless steel screw electrodes were threaded through the skull bilaterally over the frontal and parietal cortex to record the EEG. One electrode threaded through the midline of the frontal bone was used as ground. Teflon-coated multistranded stainless steel wires with $2 \mathrm{~mm}$ exposed at the tips (Goodfellow Sarl) were placed in the dorsal neck muscles to record the EMG. EEG and EMG leads were attached to a connector (MS363; Plastics One) and fixed to the skull with dental acrylic.

Recording. For registration, the electrodes were connected to a preamplifier (8213; Pinnacle Technology) through the plastic connector. This preamplifier avoids the registration of electrical interferences. The preamplifier was connected to a rotating swivel allowing free animal movements, and the swivel was connected to the EEG/EMG Data Conditioning and Acquisition System (8206; Pinnacle Technology), which was USB linked to a computer. Signal acquisition was performed using the Sirena acquisition suite (Pinnacle Technology). The EEG and EMG were recorded at a frequency of $400 \mathrm{~Hz}$. Both EEGs were lowpass filtered at $40 \mathrm{~Hz}$. EMG signals were highpass filtered at $10 \mathrm{~Hz}$ and subjected to a $100 \mathrm{~Hz}$ lowpass cutoff. After surgery, rats were individually housed in Plexiglas cages ( $30 \mathrm{~cm}$ diameter, $40 \mathrm{~cm}$ high), and left undisturbed for a postsurgery recovery period of 2 weeks. During the second week of recovery, rats were habituated to the EEGs/EMG recording procedure for the following 2 weeks. Habituation consisted of two recording sessions of $8 \mathrm{~h}$ and one session of $24 \mathrm{~h}$. At the end of the habituation period, the day of the experiment, EEGs/EMG recordings started $1 \mathrm{~h}$ after the light switch-on and continued for the next $8 \mathrm{~h}$. Two hours after the beginning of the registration, kainate (Tocris Bioscience) was injected intraperitoneally at doses $(7 \mathrm{mg} / \mathrm{kg})$ in the same range as those reported by previous studies (Sperk et al., 1983; Berg et al., 1993), and were proven to cause full limbic motor seizures in control rats. The presence of characteristic spikes and/or spike clusters activity was correlated to each stage of behavioral seizure, after kainate injection.

Kainate-induced seizures. Motor seizures were observed for $4 \mathrm{~h}$ following systemic kainate injection, and manually scored according to Racine (1972), as follows: 0, absence of seizures; 1, staring spells, immobilization, and hypoactivity; 2 , paroxysmal wet dog shake and head nodding; 3 , motor seizures associated with masticatory movements and tail arching; 4 , rearing with forelimb jerks and salivation; 5 , generalized convulsions with loss of postural control and intense myoclonic jerks lasting at least $1 \mathrm{~h}$; and 6, "full status epilepticus" and death.

\section{Assessment of anxiety-like behavior}

We assessed anxiety-like behavior in control and PRS rats by using the elevated plus maze (EPM) and the light-dark tests. All animals used for ex vivo measurements of neurotransmitter release and immunoblot analysis of protein expression had been tested for anxiety-like behavior at least 1 week earlier. The EPM test was performed essentially as described by Pellow et al., 1985. The test was performed between 13:00 and 16:00 h, lasted for $5 \mathrm{~min}$, and began with the placement of the rat in the center of the maze with the head facing a closed arm. The time spent in open and closed arms was recorded on-line by a video camera and the percentage of time spent in open arms was calculated. We also measured the number of entries into the open and closed arms, the number of crossings through the center, the number of episodes of head dips over the size of the maze, the number of episodes of rearing, and the latency to enter the open and the closed arms.

The light and dark box setup consisted of two compartments: one light compartment $(45 \times 32 \times 32 \mathrm{~cm}, 50$ lux; light box $)$ and one dark compartment $(30 \times 32 \times 32 \mathrm{~cm}, 5 \mathrm{lux})$. The compartments were connected via a small opening $(10 \times 15 \mathrm{~cm})$ enabling transition between the two boxes. Rats were placed in the light compartment and the time spent in each compartment and the latency to the first entry into the light compartment during the 5 min test, were assessed on-line via a video camera located above the box. Behavior was automatically analyzed using video tracking software (View Point).

\section{Microinfusions of CGP52432 and LY341495 in the ventral hippocampus}

All control and PRS rats used for these experiments had been tested for anxiety at the light-dark box 1 week before surgery. Rats were injected intraperitoneally with an anesthetic solution containing ketamine (100 $\mathrm{mg} / \mathrm{kg})$, xylazine $(8 \mathrm{mg} / \mathrm{kg})$, and acepromazine $(1 \mathrm{mg} / \mathrm{kg})$, placed into a David Kopf stereotaxic apparatus with the incisor bar $5.0 \mathrm{~mm}$ above the interaural line, and bilaterally implanted with permanent cranial guide cannulae (22 gauge; Plastic One) into the ventral hippocampus (anteroposterior +5.5 ; mediolateral \pm 4.5 ; dorsoventral $-5.5 \mathrm{~mm}$ from bregma and skull; Paxinos and Watson, 2007). Cannulae were fixed with dental acrylic cement directly anchored to the skull. After surgery, obturators were inserted into the guide cannulae, rats were returned to their home cage and were left undisturbed for a 7-10 d recovery period. Twelve control and 12 PRS rats were selected for microinfusion experiments and behavioral analysis. LY341495 and CGP52432 were dissolved in PBS (1.05 mM KH $\mathrm{PO}_{4}, 2 \mathrm{Na}_{2} \mathrm{HPO}_{4}, 3 \mathrm{~mm} \mathrm{H} \mathrm{H}_{2} \mathrm{O}, 154 \mathrm{~mm} \mathrm{NaCl}$, pH 7.4) to obtain final concentrations of $100 \mathrm{pg} / \mu \mathrm{l} \mathrm{LY} 341495$ and $1 \mathrm{ng} / \mu \mathrm{l}$ CGP52432. After $2 \mathrm{~d}$ of habituation to microinjection procedures, two groups of control and two groups of PRS rats received bilateral injections of either PBS alone (vehicle) or PBS containing CGP52432 and LY341495. The internal injection cannulae were connected to lengths of polyethylene tubing that in turn were connected to $10.0 \mu$ l Hamilton syringes. Injections were made bilaterally in a volume of $1 \mu \mathrm{l} /$ side over a period of $2 \mathrm{~min}$. After $1 \mathrm{~min}$, the injection cannulae were withdrawn, the obturators replaced, and rats were returned to their home cage for $15 \mathrm{~min}$ before the start of behavioral assessments. All rats underwent two consecutive tests of $5 \mathrm{~min}$ in the light-dark box and the EPM, as described above. The two tests were performed one immediately after the other. This behavioral protocol may confound data of the second test (the EPM) because the stress associated with the execution of the first test (the light-dark box) might differentially affect the performance in the EPM in the four group of rats (control rats injected with vehicle, PRS rats injected with vehicle, control rats injected with CGP52432 plus LY341495, and PRS rats injected with CGP52432 plus LY341495. Despite these potential limitations, the execution of two consecutive tests was necessary to avoid the bias of reinjecting the mixture of drugs in the same animals without having knowledge of the neuroadaptive changes that intrahippocampal injection of CGP52432 and LY341495 may cause.

The correct position of the guide cannula in the ventral hippocampus was confirmed in all rats by injection of $1 \mu \mathrm{l}$ of methylene blue $(5 \%$, dissolved in saline).

\section{Western blot analysis}

Two groups of control and PRS rats ( $n=6$ per group) were killed by decapitation and the ventral and dorsal portions of the hippocampus were rapidly dissected (Robertson et al., 2005). To isolate synaptosomes, tissue was manually homogenized with a potter in 10 vol of HEPESbuffered sucrose (0.32 M sucrose, 4 mM HEPES, $\mathrm{pH} 7.4)$. All procedures were performed at $4^{\circ} \mathrm{C}$. Homogenates were centrifuged at $1000 \times g$ for 10 $\min$ and resulting supernatants were centrifuged at $10,000 \times g$ for 15 min. The pellet obtained from the second centrifugation was resuspended in $10 \mathrm{vol}$ of HEPES-buffered sucrose and then spun again at $10,000 \times g$ for $15 \mathrm{~min}$. This pellet contained the crude synaptosomal fraction. To validate the purity of this synaptosomal fraction we used antihiston $\mathrm{H} 3$, anti- $\beta$-tubulin, anti-synapsin Ia/b in immunoblot analysis. BCA assay was used to determine protein concentration. Synaptosomes lysates 
were resuspended in Laemmli reducing buffer and $20 \mu \mathrm{g}$ of each sample were first separated by electrophoresis on Criterion TGX 4-15\% precast SDS-polyacrylamide gels (Bio-Rad) and later transferred to nitrocellulose membranes (Bio$\mathrm{Rad}$ ). Transfer was performed at $4^{\circ} \mathrm{C}$ in a buffer containing $35 \mathrm{~mm}$ TRIS, $192 \mathrm{~mm}$ glycine, and $20 \%$ methanol. We used the following primary antibodies: rabbit polyclonal anti-synapsin Ia/b (sc-20780, 1:4000), rabbit polyclonal antisynapsin IIa (sc-25538, 1:4000), rabbit polyclonal anti-synaptophysin (sc-9116, 1:80,000), rabbit polyclonal anti-VAMP (synaptobrevin, sc13992, 1:2000), rabbit polyclonal anti-syntaxin-1 (sc-13994, 1:5000), and mouse monoclonal antiSNAP-25 (sc-136267, 1:10000) (all purchased from Santa Cruz Biotechnology); mouse monoclonal anti-rab3a (107111, 1:2000), mouse monoclonal anti-Munc-18 (116011, 1:2000), mouse monoclonal anti-VGLUT-1 (135511, 1: 2000), rabbit polyclonal anti-GluK3 (180203, 1:1000), and rabbit polyclonal GluK5 (180103, 1:1000) (all purchased from Synaptic System); rabbit polyclonal anti-Gluk1 (AGC-008, 1:1000) and rabbit polyclonal anti-GluK2 (AGC-009, 1:1000) (both purchased from Alomone Labs); rabbit polyclonal anti-GluK4 (ab67404, 1:1000) (purchased from Abcam); rabbit polyclonal antiGLAST (GLAST11-A, 1:1000), rabbit polyclonal anti-GLT-1 (GLT11-A, 1:1000), and rabbit polyclonal anti-EAAC-1 (EAAC11-A, 1:1000) (all purchased from Alpha Diagnostic International); and mouse monoclonal anti- $\beta$-actin (A5316, 1:80,000) (purchased from Sigma). Secondary anti-mouse or anti-rabbit antibodies (purchased from GE Healthcare) were used a dilution at 1:10,000.

Densitometric analysis was performed with Quantity One software (Bio-Rad) associated to a GS-800 scanner. The ratio of individual proteins to $\beta$-actin was then determined and these values were compared for statistical significance.

\section{Statistical analysis}

Data of release experiments, immunoblot analysis, and behavioral data with light-dark box and EPM (excluding data obtained in microinfused animals) were analyzed by Student's $t$ test (PRS vs control rats). Data of kainate-induced seizures were analyzed by two-way ANOVA for repeated measures followed by the Neumann-Keuls post hoc. Behavioral data obtained after microinfusions with vehicle or CGP52432 + LY341495 were analyzed by two-way ANOVA (group $X$ treatment) followed by the Neumann-Keuls post hoc. A $p$ value $<0.05$ was considered as statistically significant.

\section{Results}

PRS selectively reduced depolarizationevoked release of glutamate in superfused synaptosomes isolated from the ventral hippocampus

To study the effects of PRS on neurotransmitter release we used superfused synaptosomes prepared from adult male PRS rats and their age-matched controls. Our superfusion method eliminates the components in neurotransmitter release mediated by the inrespective controls.
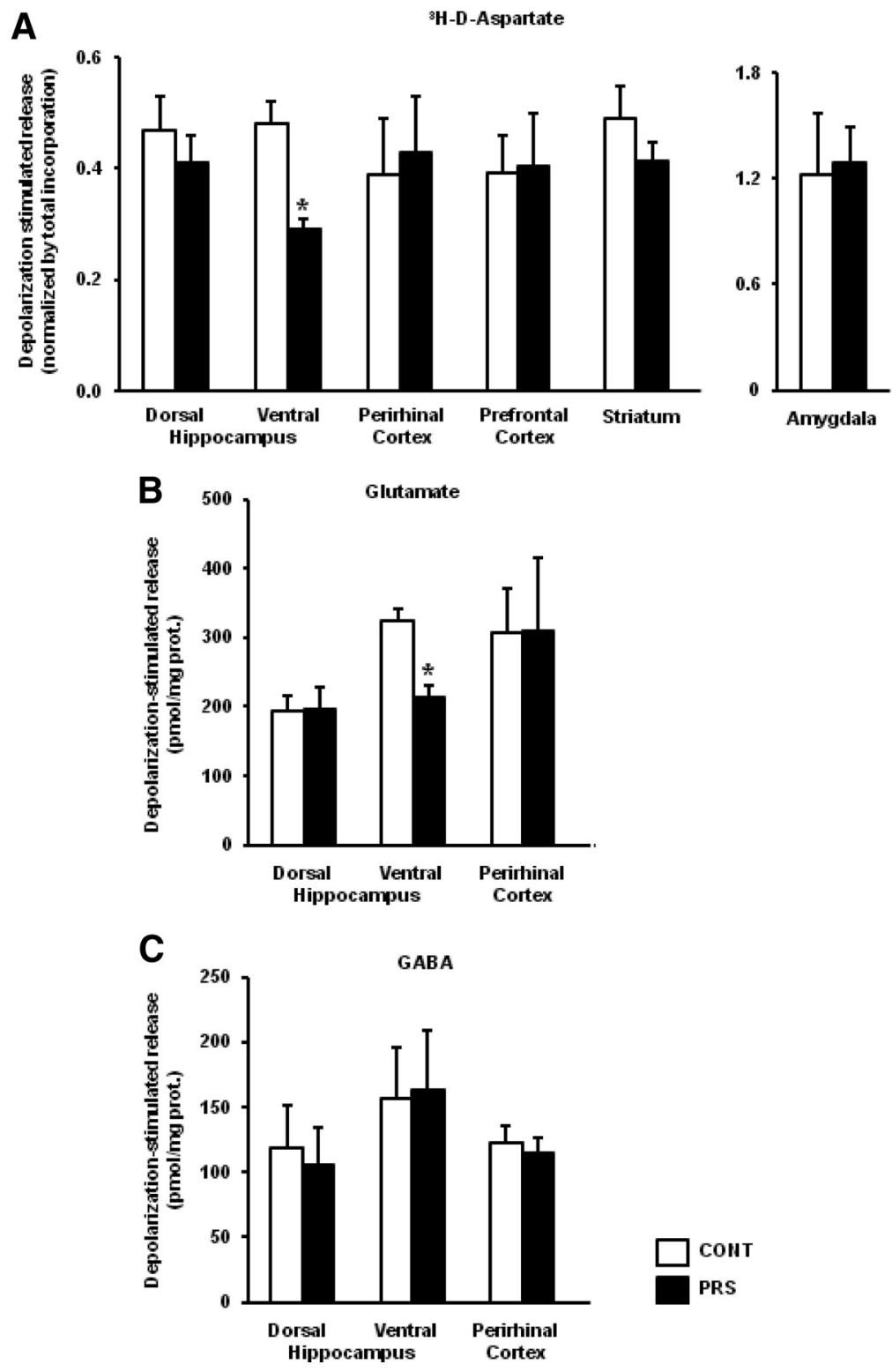

Figure 1. PRS causes a selective impairment of depolarization-evoked glutamate release in synaptosomes from the ventral hippocampus. Superfused synaptosomal preparations from the dorsal and ventral hippocampus, perirhinal cortex, prefrontal cortex, striatum, or amygdala of control (CONT) or PRS rats (one control and one PRS animal in each experiment) were stratified at the bottom of superfusion chambers (three superfusion chambers for each synaptosomal preparation) and superfused as described (see Materials and Methods). The total $\left[{ }^{3} \mathrm{H}\right] \mathrm{D}$-ASP content in the synaptosomal fraction at the start of the superfusion period amounted, respectively, to control dorsal hippocampus: $221.34 \pm 14.75 \mathrm{nCi}$; PRS dorsal hippocampus: $226.44 \pm 13.58 \mathrm{nCi}$, not significant (n.s.); control ventral hippocampus: $273.21 \pm 37.02$ nCi; PRS ventral hippocampus: $232.45 \pm 21.32$ nCi, n.s.; control perirhinal cortex: $341.14 \pm 44.81$ nCi; PRS perirhinal cortex: $298.31 \pm 46.23$ nCi, n.s.; control prefrontal cortex: $209.30 \pm 18.33$ nCi; PRS prefrontal cortex: $218.82 \pm 23.44$ nCi, n.s.; control striatum: $238.55 \pm 15.56$ nCi; PRS striatum: $246.07 \pm 30.47$ nCi, n.S.; control amygdala: $191.13 \pm 10.09$ nCi; PRS amygdala: $176.89 \pm 16.89$ nCi, n.s. Data are expressed as nCi/chamber and correspond to the amount of radioactive tracer taken up by each synaptosomal preparation. At $t=39$ min of superfusion, synaptosomes were challenged with 20 (amygdala) or 12 (all other regions) $\mathrm{mm} \mathrm{K}^{+}$. Synaptosomes were used for measurements of $\mathrm{D}-\left[{ }^{3} \mathrm{H}\right]$ aspartate $(\boldsymbol{A})$, glutamate $(\boldsymbol{B})$, or GABA $(\boldsymbol{C})$ release. Data are expressed as $\mathrm{K}^{+}$-induced overflow. Glutamate and GABA overflow is expressed as pmol/mg prot. The evoked release of $\mathrm{D}-\left[{ }^{3} \mathrm{H}\right]$-aspartate is expressed as the percentage of the total tritium content in synaptosomes. High $\mathrm{K}^{+}$depolarization-induced overflow is expressed as stimulated release over basal release. Values are means \pm SEM of six experiments run in triplicate (3 superfusion chambers for each experimental condition). ${ }^{*} p<0.01$ versus the

verse operation of membrane transporters and the influence of endogenous ligands acting at presynaptic receptors, thus allowing a reliable estimation of how the intrinsic release machinery responds to depolarization or other stimuli (Raiteri et al., 1974; Raiteri and Raiteri, 2000). Depolarization-evoked release in this 
A
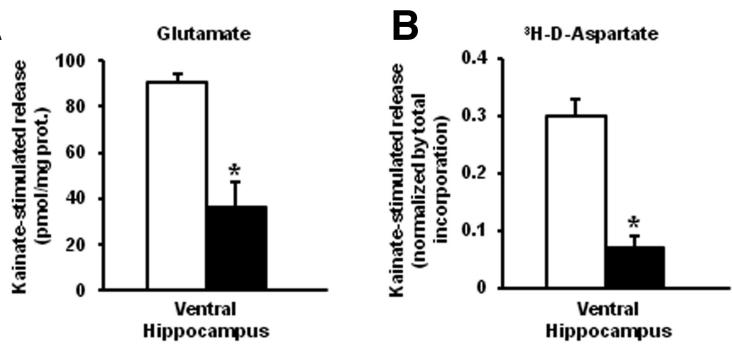

C

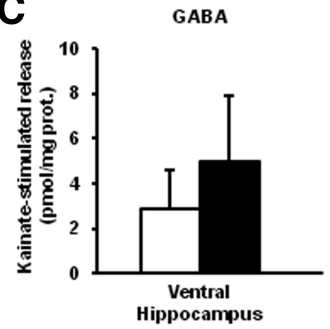

D
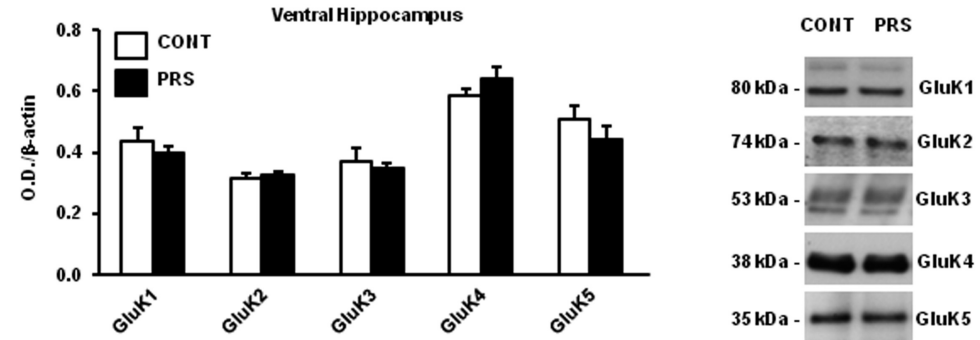

Kainate-inducedEEG alteration: score levels

E

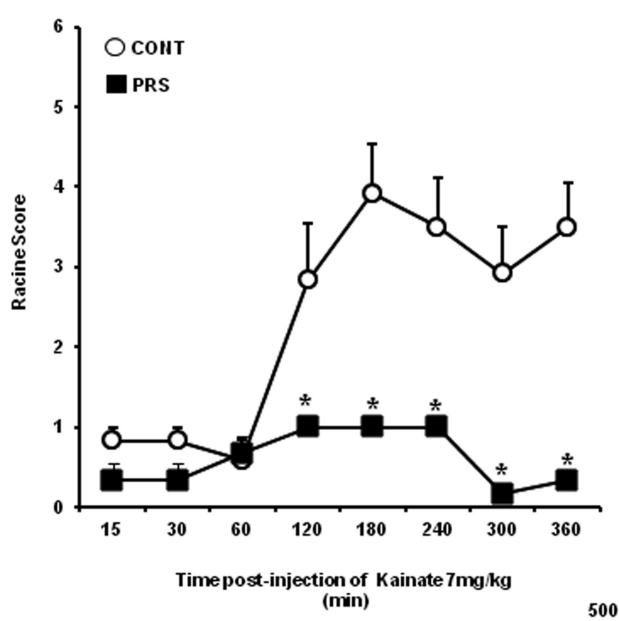

Kainate-inducedEEG alter

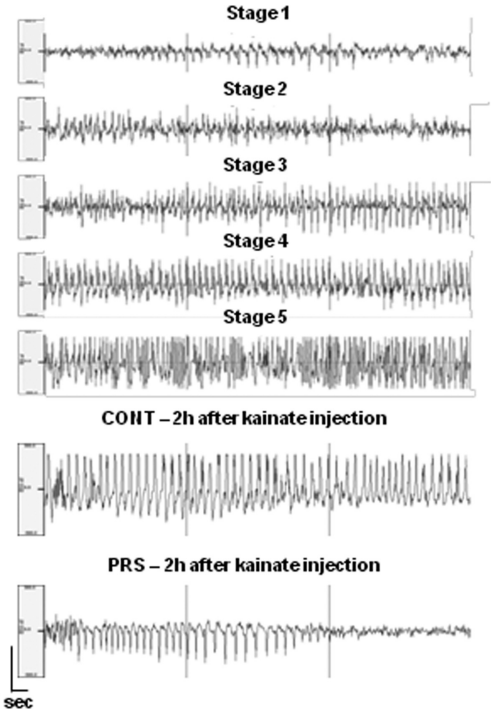

Figure 2. Reduced kainate-stimulated glutamate release in the ventral hippocampus and kainate-induced limbic motor seizures in PRS rats. Kainate-induced release of glutamate, $\mathrm{D}-\left[{ }^{3} \mathrm{H}\right]$-aspartate, and GABA in superfused synaptosomes prepared from the ventral hippocampus of control (CONT) or PRS rats are shown in $\boldsymbol{A}, \boldsymbol{B}$, and $\boldsymbol{C}$, respectively. Data are expressed as reported in Figure 1, as kainate-induced overflow. Values are means \pm SEM of six experiments run in triplicate (3 superfusion chambers for each experimental condition). ${ }^{*} p<0.05$ or $p<0.01$ versus the respective controls. Immunoblot analysis of GluK1-5 kainate receptor subunits in the ventral hippocampus of control and PRS rats is shown in $\boldsymbol{D}$. Values are means $\pm \mathrm{SEM}$ of six determinations. Behavioral score of kainate-induced seizures in control and PRS rats is shown in $\boldsymbol{E}$. Kainate was injected at the dose of $7 \mathrm{mg} / \mathrm{kg}$, intraperitoneally. Values are means \pm SEM of six determinations. ${ }^{*} p<0.01$ versus the respective data obtained in control rats. Representative EEG traces corresponding to different stages of kainate-induced seizures and representative traces obtained in control and PRS at $2 \mathrm{~h}$ following kainate injection.

system is exocytotic and entirely depended on extracellular $\mathrm{Ca}^{2+}$ (Bonanno et al., 2005). Synaptosomes prepared from the ventral and dorsal hippocampus, perirhinal cortex, prefrontal cortex, striatum, and amygdala from control or PRS rats were preloaded with $\mathrm{D}-\left[{ }^{3} \mathrm{H}\right]$-aspartate (a nonmetabolizable analog of glutamate), and then challenged with depolarizing concentrations of $\mathrm{K}^{+}$. Both uptake and basal (nonevoked) release of $\mathrm{D}-\left[{ }^{3} \mathrm{H}\right]$-aspartate in all brain regions did not differ between control and PRS rats. In contrast, depolarization-evoked D- $\left[{ }^{3} \mathrm{H}\right]$-aspartate release was selectively and substantially reduced in synaptosomes prepared from the ventral hippocampus of PRS rats $(t=10.70 ; d f=10$; $p<0.01)$. No difference in depolarization-evoked $\mathrm{D}-\left[{ }^{3} \mathrm{H}\right]-$ aspartate release between control and PRS rats was seen in all other brain regions (Fig. 1A). In a different set of experiments, synaptosomes from ventral and dorsal hippocampus and perirhinal cortex were challenged with depolarizing concentrations of $\mathrm{K}^{+}$, and the superfusate was used for measurements of endogenous glutamate and GABA release. Again, depolarization-evoked glutamate release was largely reduced in the ventral hippocampus of PRS rats $(t=4.70 ; d f=10$; $p<0.01$ ), with no changes in the dorsal hippocampus or perirhinal cortex (Fig. 1B). Neither basal nor evoked GABA release differed between control and PRS rats in any brain region (Fig. $1 C$ ).

PRS reduced both kainate-evoked glutamate release in the ventral hippocampus and behavioral responses to kainate

To examine whether the difference between control and PRS rats was stimulus specific, we also challenged synaptosomes with kainic acid. At least in our superfusion system, kainate (10 $\mu \mathrm{M})$ substantially enhanced both glutamate and GABA release. Again, a substantial reduction in kainate-stimulated glutamate $(t=2.28$; $d f=10 ; p<0.05)$ and $\mathrm{D}-\left[{ }^{3} \mathrm{H}\right]$-aspartate $(t=25.89 ; d f=10 ; p<0.01)$ release was found in the ventral hippocampus of PRS rats (Fig. $2 A, B$ ). In contrast, kainatestimulated GABA released was unchanged in synaptosomes prepared from the ventral hippocampus of PRS rats (Fig. 2C). To exclude that the reduction in kainatestimulated glutamate release in the ventral hippocampus was due to changes in the expression of kainate receptors, we measured the levels of kainate receptor subunits (GluK1-5) by immunoblotting. GluK1-5 protein levels did not differ between PRS rats and control rats (Fig. 2D). As a behavioral counterpart of the study of kainate on glutamate release, we examined kainate-induced motor seizures in control and PRS rats. Systemic injection of kainate $(7 \mathrm{mg} / \mathrm{kg}$, i.p.) in control rats induced secondarily generalized partial limbic motor seizures characterized by motor arrest, wet dog shake, head nodding, masticatory movements, and rearing with forepaw clonus. Some control rats developed generalized tonicclinic seizures and status epilepticus. Interestingly, kainateinduced seizures were largely reduced in PRS rats (group $\times$ time $F_{(1,8)}=11.31, p<0.01$ ) (Fig. $2 E$ ). The average seizure severity score of PRS rats at 120-240 min following kainate injection was around " 1 " of the Racine scale. In contrast, the average score of control rats was between 3 and 4 at 120 min following kainate injection. None of PRS rats showed generalized seizures and status epilepticus in response to kainate (Fig. 2E). PRS and control rats did not differ in the temporal latency to the induction of 
motor seizures. Representative EEG traces corresponding to a score of 1 to 5 of the Racine scale are shown in Figure 2E. Typical EEG recording of control and PRS rats at $2 \mathrm{~h}$ following kainate injection are also shown (Fig. 2E).

The reduction of evoked glutamate release was associated with lower expression of synaptic vesicle-related proteins in the ventral hippocampus of PRS rats

We measured the levels of synaptic vesicle-associated proteins and membrane glutamate transporters in purified synaptosomal membranes prepared from the ventral and dorsal hippocampus of control and PRS rats. Substantial reductions in the levels of Rab3A $(t=4.76, d f=$ $10 ; p<0.01)$, Munc-18 $(t=2.78 ; d f=10$; $p<0.05)$, VAMP (synaptobrevin) $(t=$ 2.91; $d f=10 ; p<0.05)$, syntaxin-1 $(t=$ 3.30; $d f=10 ; p<0.01)$, synaptophysin $(t=3.41 ; d f=10 ; p<0.01)$, synapsin Ia/b $(t=2.65 ; d f=10 ; p<0.05)$, and synapsin IIa $(t=5.41 ; d f=10 ; p<0.01)$ were found in the ventral hippocampus of PRS rats (Fig. 3A), whereas levels of SNAP25, and the glutamate transporters, v-Glut1, GLAST EACC-1, and GLT-1 did not change (Fig. 3B). Levels of synapsin $\mathrm{Ia} / \mathrm{Ib}$ were lowered by as much as $60 \%$ and levels of syntaxin by $\sim 50 \%$ in the ventral hippocampus of PRS rats. We only found reductions in the levels of synapsin $\mathrm{Ia} / \mathrm{Ib}$ $(t=2.70 ; d f=10 ; p<0.05)$ and syntaxin $(t=3.30 ; d f=10 ; p<0.01)$, and an increase in the levels of ${ }_{\mathrm{v}}$-Glut1 $(t=2.90$; $d f=10 ; p<0.05)$ in the dorsal hippocampus of PRS rats (Fig. 3C,D). Levels of all other proteins did not change in the dorsal hippocampus.

The reduction in depolarization-evoked glutamate release in the ventral

hippocampus correlated positively with anxiety-like behavior in PRS rats

PRS rats show anxiety-like behavior

(Vallée et al., 1997; Zuena et al., 2008; Morley-Fletcher et al., 2011), and the ventral portion of the hippocampus is involved in emotion and anxiety (Fanselow and Dong, 2010). Hence, we examined the correlation between depolarization-evoked glutamate release in the ventral hippocampus and anxiety-like behavior in control and PRS rats. Both control and PRS rats used for measurements of glutamate release in synaptosomes (see above) had been tested for anxiety-like behavior in the EPM. PRS rats spent less time in the open arm of the EPM, as expected $(t=3.40$; $d f=10 ; p<0.01$ ) (Fig. $4 A$ ). We found a positive correlation between the time spent by animals in the open arm of the EPM and the extent of depolarization-stimulated glutamate release in the ventral hippocampus $(r=0.90 ; p<0.01)$, indicating that anxiety-like behavior was inversely related to the evoked release of glutamate (Fig. 4B). We extended the study to additional
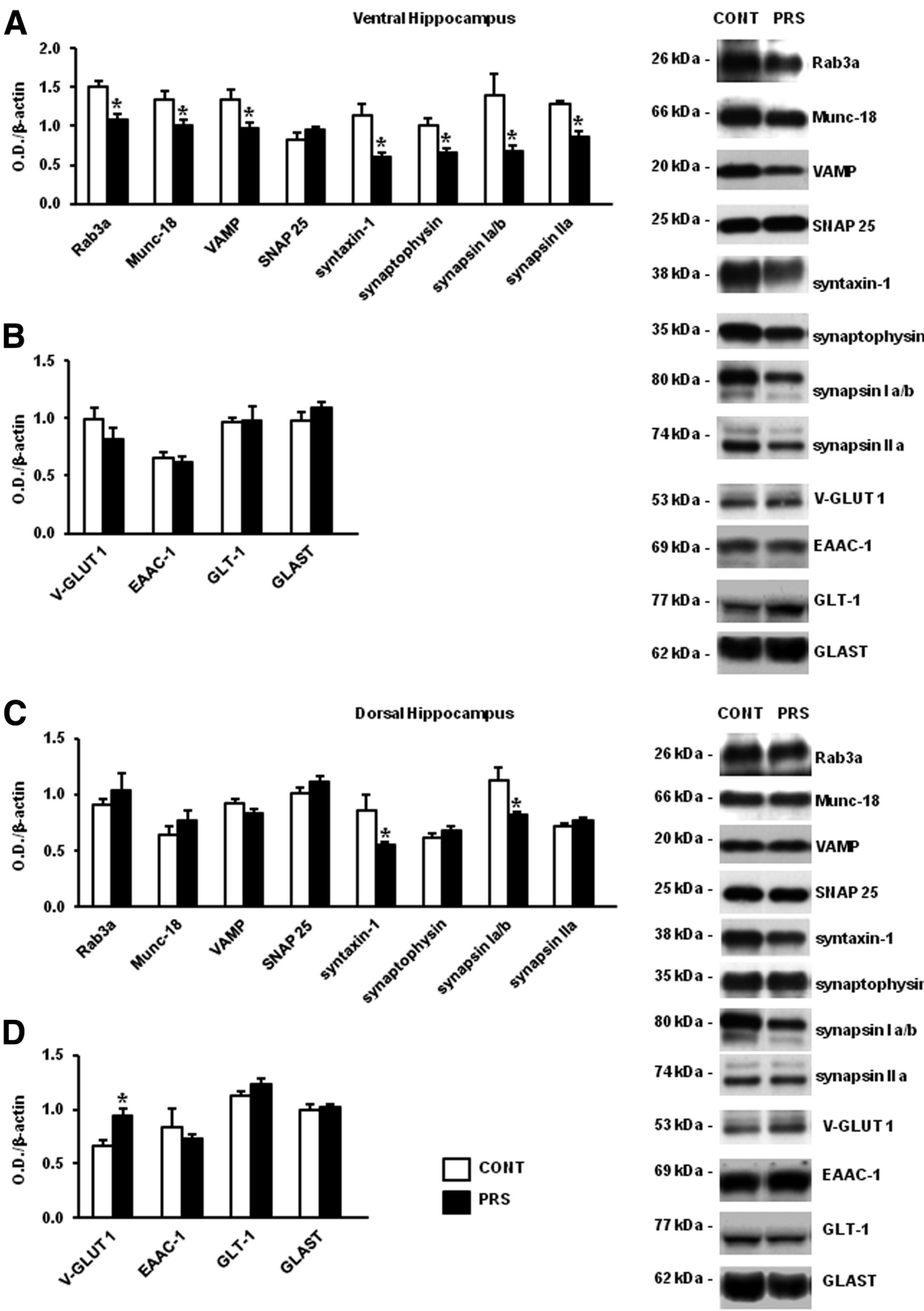

Figure 3. PRS reduced expression of synaptic vesicle-associated proteins in the ventral hippocampus. Immunoblot analysis of SNARES, vesicle-associated proteins, and glutamate transporters in synaptosomal fractions collected from the ventral $(\boldsymbol{A}, \boldsymbol{B})$ and dorsal $(\boldsymbol{C}, \boldsymbol{D})$ hippocampus of adult PRS and control (CONT) male rats. Values are means \pm SEM of six determinations. ${ }^{*} p<0.05$ or $p<0.01$ versus the respective controls.

groups of control and PRS rats tested for anxiety-like behavior in the light-dark box. PRS rats spent less time in the light compartment of the light-dark box $(t=2.90 ; d f=10 ; p<0.05)$ (Fig. $4 C$ ). There was a positive correlation between the time spent by control and PRS rats in the light compartment and the extent of depolarization-stimulated glutamate release in the ventral hippocampus $(r=0.89 ; p<0.01$; Fig. $4 D)$, confirming the inverse correlation between anxiety-like behavior and glutamate release.

Pharmacological enhancement of glutamate release in the ventral hippocampus corrects anxiety-like behavior in PRS rats

To examine whether the reduction of glutamate release in the ventral hippocampus was causally related to anxiety-like behavior in PRS rats we used a mixture of drugs that block presynaptic 
A
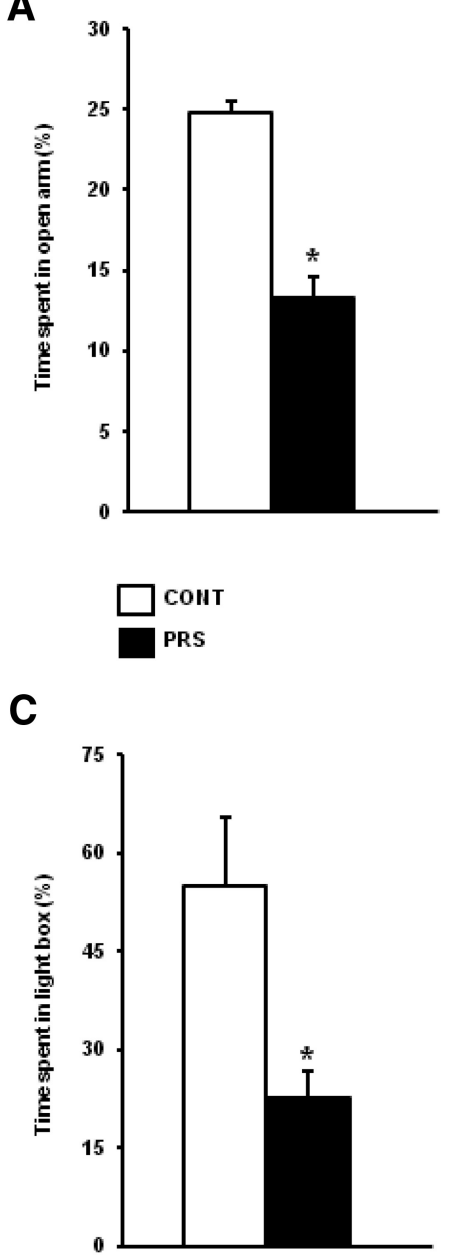

B

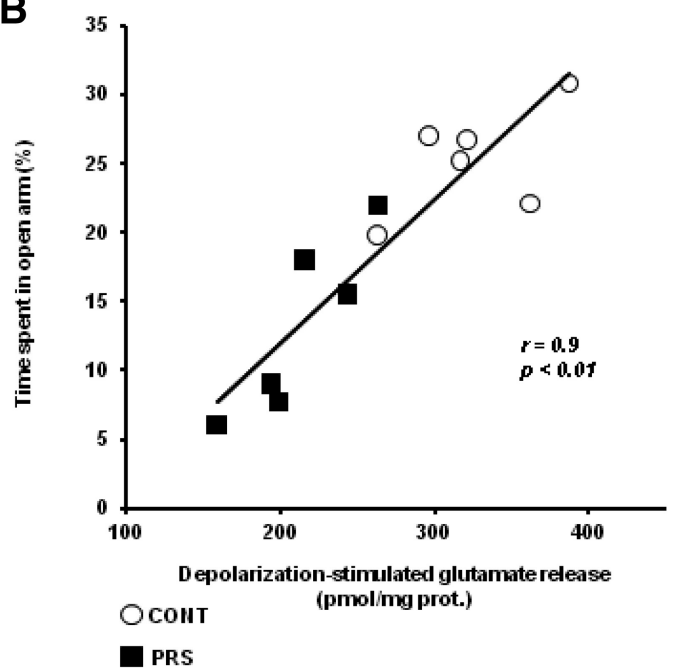

D

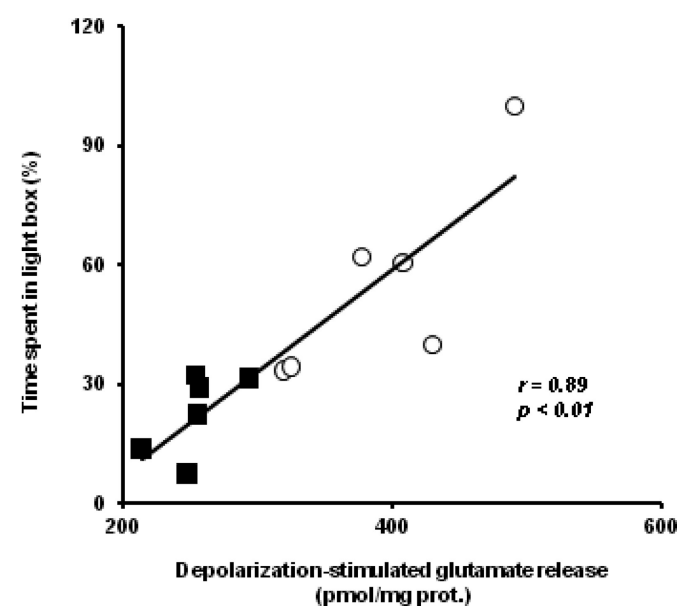

Figure 4. Negative correlation between depolarization-evoked release in the ventral hippocampus and anxiety-like behavior. Anxiety-like behavior in the EPM and light-dark box is shown in $\boldsymbol{A}$ and $\boldsymbol{C}$, where the time spent in the open arm of the EPM and in the light compartment of the light-dark box is shown. Different groups of rats were used for behavioral analysis in the EPM and light-dark box. Data are means \pm SEM of six determinations. ${ }^{*} p<0.01$ or $p<0.05$ versus the respective controls. Correlation analysis between the time spent in the open arm of the EPM or in the light compartment of the light-dark box and depolarizationevoked glutamate release in synaptosomes prepared from the ventral hippocampus of control (CONT) and PRS rats is shown in $\boldsymbol{B}$ and $\boldsymbol{D}$, respectively.

type-2/3 metabotropic glutamate (mGlu2/3) receptors and $\mathrm{GABA}_{\mathrm{B}}$ receptors. These receptors are known to negatively regulate glutamate release in the hippocampus and other brain regions (reviewed by Chalifoux and Carter, 2011; Nicoletti et al., 2011). We combined the selective $\mathrm{GABA}_{\mathrm{B}}$ receptor antagonist, CGP52432 (Lanza et al., 1993) with the preferential mGlu2/3 receptor antagonist, LY341495 (Schoepp et al., 1999). To examine whether this mixture was able to enhance glutamate release we could not use isolated synaptosomal preparations because the method of superfused synaptosomes eliminates the influence of endogenously activated presynaptic receptors on neurotransmitter release (see above). Thus, we measured D- $\left[{ }^{3} \mathrm{H}\right]$-aspartate release in preloaded hippocampal slice preparations. We used saturating concentrations of CGP52432 and LY341495 (10 and 1 $\mu \mathrm{M}$, respectively). At these concentrations, LY341495 is still a preferential blocker of $\mathrm{mGlu} 2 / 3$ receptors with respect to other mGlu receptor subtypes (Schoepp et al., 1999). The addition of CGP52432 and LY341495 enhanced high-K ${ }^{+}$(30 mM) evoked $\mathrm{D}-\left[{ }^{3} \mathrm{H}\right]$-aspartate release in slices prepared from the ventral hip-

pocampus of both control and PRS rats $(39 \pm 14$ and $29 \pm 8 \%$ above values obtained with $30 \mathrm{mM} \mathrm{K}^{+}$alone, respectively; $n=5$ ), without affecting basal $\mathrm{D}-\left[{ }^{3} \mathrm{H}\right]-$ aspartate release. Interestingly, the mixture of CGP52432 and LY341495 had no effect on depolarization-evoked $\mathrm{D}-\left[{ }^{3} \mathrm{H}\right]$ aspartate release in slices from the dorsal hippocampus of control and PRS rats (data not shown). We therefore decided to study anxiety-like behavior in control and PRS rats after bilateral microinfusion of CGP53432 plus LY341495 in the ventral hippocampus. Based on previous studies (Jackson and Kuehl, 2002; Barker et al., 2006; Li and Pan, 2007; Dong et al., 2012) we first tested three doses of CGP53432 (1 ng, $10 \mathrm{ng}$, or $50 \mathrm{ng}$ ) always combined with $100 \mathrm{pg}$ of LY341495. The mixture containing $10 \mathrm{ng}$ or $50 \mathrm{ng}$ of CGP53432 increased rearing and wet dog shake, whereas the mixture containing 1 ng of CGP53432 did not cause changes in motor activity or spontaneous motor behavior in control rats. Thus, we decided to use $1 \mathrm{ng}$ of CGP53432 combined with 100 pg of LY341495 for the study of anxietylike behavior in control and PRS rats. All animals used for this study had been tested for anxiety-like behavior in the light-dark box 14-17 d before microinfusion experiments (Fig. 5A). Following microinfusion with vehicle or CGP52432 plus LY341495 all animals were consecutively tested in the light-dark box and in the EPM. This behavioral protocol is unusual because data of the second test (the EPM) might have been confounded by the effects of the first test (the light-dark box). However, we adopted this strategy to examine the effect of CGP52432 and LY341495 in two different tests of anxiety without the need to reinject the drugs in the ventral hippocampus. PRS rats infused with vehicle in the ventral hippocampus spent less time in the light compartment of the light-dark box, as expected. This paradigm of anxiety-like behavior was corrected by the mixture of CGP53432 and LY341495. Intrahippocampal infusion of CGP52432 and LY341495 had no effect on control unstressed rats (group $\times$ treatment, $F_{(1,20)}=5.40 ; p<0.05 ; n=6$ per group; Fig. $5 B)$. PRS rats treated with vehicle showed also an increased latency to enter the light compartment of the box, which, again, was corrected by treatment with CGP53432 and LY341495 (group $\times$ treatment, $F_{(1,20)}=33.54 ; p<0.01$; Table 1). In contrast, the number of entries into the light and dark compartment did not differ among the four groups of rats (Table 1). The "curative" effect of CGP53432 and LY341495 on anxiety-like behavior of PRS rats was supported by EPM data. PRS rats treated with vehicle, but not PRS rats treated with CGP53432 plus LY341495, spent less time in the open arm of the EPM (group $\times$ treatment, $F_{(1,20)}=18.16 ; p<0.01 ; n=6$ per group; Fig. $5 C$ ). PRS rats treated with vehicle also showed a reduced number of entries into the open arm, a reduced number of episodes of head dips (which 

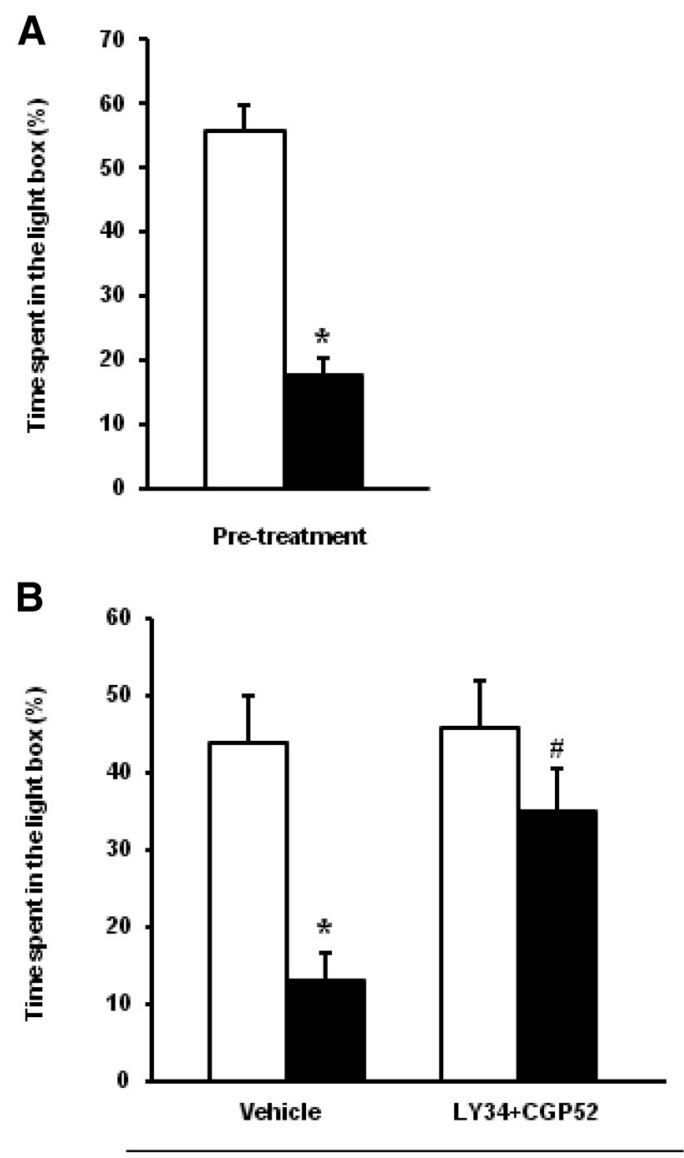

Post-treatment

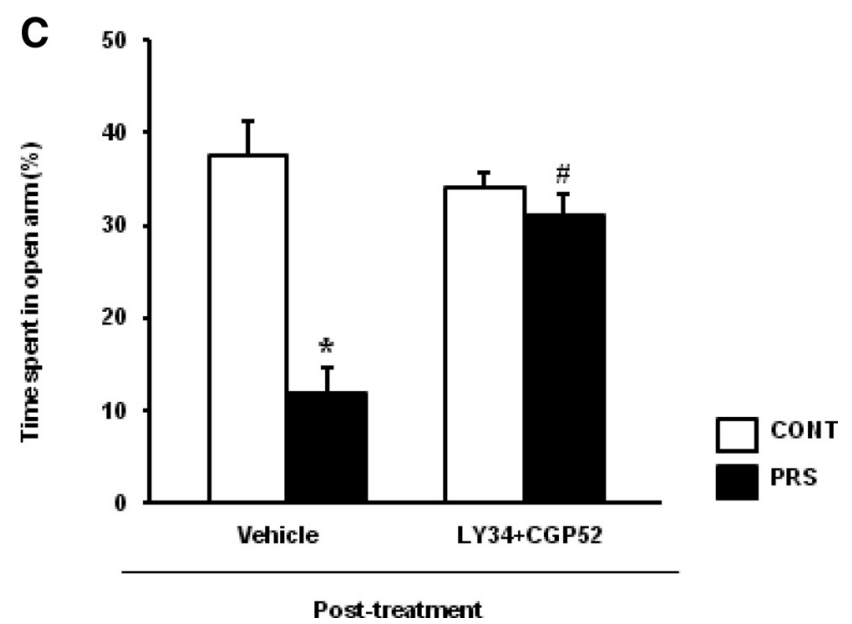

Figure 5. Pharmacological enhancement of glutamate release corrects anxiety-like behavior in PRS rats. All rats were tested in the light-dark box 1 week before surgery (i.e., 14-17 d before drug microinfusions in the ventral hippocampus). The time spent in the light compartment of the light-dark box in this pretest performed $14-17 \mathrm{~d}$ before is shown in $\boldsymbol{A}$. Values are means \pm SEM of 12 control (CONT) and 12 PRS rats. ${ }^{*} p<0.01$ versus control rats. Behavioral data obtained in unstressed and PRS rats following microinfusion of vehicle or CGP52432 plus LY341495 in the ventral hippocampus are shown in $\boldsymbol{B}$ and $\boldsymbol{C}$. Animals were first tested in the light- dark box and immediately after in the EPM. The effects of the first test experience might confound the interpretation of data of the second test (the EPM). However, the mixture of CGP52432 and LY341495 reduced anxiety-like behavior in PRS rats in both tests. The time spent in the open arm of the EPM and in the light compartment of the light-dark box in control and PRS rats bilaterally infused with $1 \mu$ I PBS containing $1 \mathrm{ng}$ of CGP52432 and $100 \mathrm{pg}$ of LY341495 or PBS alone (vehicle) in the ventral hippocampus are shown in $\boldsymbol{B}$ and $\boldsymbol{C}$, respectively. Values are means \pm SEM of six rats per group. $p<0.01$ or $p<0.05$ versus the respective control values $\left({ }^{*}\right)$ or versus the respective values treated with vehicle (\#).
Table 1. Number of entries and latency to enter the two compartments of the light-dark box in control and PRS rats bilaterally infused with vehicle or CGP53432 plus LY341495 into the ventral hippocampus

\begin{tabular}{llc}
\hline & $\begin{array}{l}\text { Number of } \\
\text { entries }\end{array}$ & $\begin{array}{l}\text { Latency to } \\
\text { enter (s) }\end{array}$ \\
\hline $\begin{array}{l}\text { CONT/vehicle } \\
\text { Light compartment }\end{array}$ & $5.5 \pm 0.6$ & \\
$\quad$ Dark compartment & $5.9 \pm 0.6$ & $28 \pm 9.0$ \\
$\begin{array}{l}\text { PRS/vehicle } \\
\text { Light compartment }\end{array}$ & $5.2 \pm 1.0$ & $228 \pm 31^{*}$ \\
$\quad$ Dark compartment & $4.7 \pm 0.9$ & $9.9 \pm 1.8$ \\
$\begin{array}{l}\text { CONT/ CGP + LY } \\
\text { Light compartment }\end{array}$ & $5.2 \pm 0.9$ & $49 \pm 7.3$ \\
Dark compartment & $5.5 \pm 0.8$ & $22 \pm 3.2$ \\
PRS/GGP + LY & & \\
$\quad$ Light compartment & $6.3 \pm 0.4$ & $35 \pm 3.8$ \\
Dark compartment & $6.8 \pm 0.4$ & $18 \pm 3.2$ \\
\hline
\end{tabular}

Data were obtained from the same control (CONT) and PRS rats of Figure $5 B$; see legend for details on treatments with CGP53432 and LY341495. Values are means \pm SEM of six rats per group. ${ }^{*} p<0.01$ versus latency to enter the light compartment in all other groups.

is a surrogate indicator for anxiety like-behavior), an increased latency to enter the open arm, and a reduced latency to enter the closed arm. Most of these alterations were corrected by treatment with CGP53432 plus LY341495 (number of entries into the open arm: group $\times$ treatment, $F_{(1,20)}=7.79 ; p<0.05$; episodes of head dips: $F_{(1,20)}=25.64 ; p<0.01$; latency to enter the open arm: $F_{(1,20)}=5.05 ; p<0.05$; latency to enter the closed arm: $F_{(1,20)}=$ $24.20 ; p<0.05$ ) (Table 2). The four groups of rats did not differ with respect to the number of entries into the closed arm, the number of crossings through the central area of the EPM, and the episodes of rearing (Table 2), excluding nonspecific effects of the treatments on motor behavior.

\section{Discussion}

We have shown for the first time that prenatal restraint stress, which is a model that recapitulates some of the features of depression and anxiety, causes a selective impairment of glutamate release in the ventral hippocampus, a brain region that specifically encodes memories related to stress and emotions (Fanselow and Dong, 2010). The reduced glutamate release in PRS rats was not due to an impaired glutamate synthesis in presynaptic terminals because it was also seen in synaptosomes preloaded with $\mathrm{D}-\left[{ }^{3} \mathrm{H}\right]$ aspartate. Martisova et al. (2012) found a reduced expression of vesicular glutamate transporters in the hippocampus of rats subjected to maternal separation, which is another model of early life stress. In contrast, VGLUT1 expression was unchanged in the ventral hippocampus of PRS rats, thus excluding a reduced glutamate transport into synaptic vesicles. Our data strongly suggest that PRS causes a long-lasting dysfunction in the intrinsic machinery controlling exocytotic glutamate release in the ventral hippocampus. Regulated neurotransmitter release depends on $\mathrm{Ca}^{2+}$ sensors, C2 domain proteins that associate with phospholipids, the three proteins of the SNARE complex (VAMP, SNAP25, syntaxin), and other proteins regulating the trafficking of synaptic vesicles, such as synaptophysin, synapsins, munc-18, and Rab3A (for review, see Han et al., 2010; Epp et al., 2011; Hussain and Davanger, 2011; Walter et al., 2011). Synaptophysin acts as a regulator of the SNARE complex (Hinz et al., 2001), and is also considered as a marker protein of presynaptic nerve endings (Thome et al., 2001; Grillo et al., 2005). Synapsins are involved in the clustering of synaptic vesicles to the reserve pool near the release sites in presynaptic terminals (Valtorta et al., 1992; Greengard et al., 1993). Munc-18 is a molecular chaperone 
Table 2. EPM data of control and PRS rats bilaterally infused with vehicle or CGP53432 plus LY341495 into the ventral hippocampus

\begin{tabular}{|c|c|c|c|c|}
\hline & CONT/vehicle & PRS/vehicle & CONT/CGP + LY & $\overline{P R S / C G P}+\mathrm{LY}$ \\
\hline Number of entries into the open arm & $5.5 \pm 0.6$ & $2.3 \pm 0.5^{a}$ & $5.0 \pm 0.4$ & $4.3 \pm 0.2$ \\
\hline Number of entries into the closed arm & $8.2 \pm 0.5$ & $7.0 \pm 0.6$ & $11 \pm 1.7$ & $9.2 \pm 0.7$ \\
\hline Number of crossings through the center & $13 \pm 0.8$ & $11 \pm 1.7$ & $13 \pm 1.2$ & $12 \pm 1.0$ \\
\hline Episodes of head dips & $11 \pm 1.5$ & $4.8 \pm 1.4^{b}$ & $14 \pm 1.4$ & $9.7 \pm 1.3^{c}$ \\
\hline Rearing episodes & $10 \pm 1.5$ & $8.8 \pm 0.5$ & $8.5 \pm 1.6$ & $10 \pm 0.9$ \\
\hline Latency to enter the open arm & $6.2 \pm 1.4$ & $71 \pm 25^{d}$ & $5.9 \pm 1.4$ & $14 \pm 2.9$ \\
\hline Latency to enter the closed arm & $37 \pm 4.2$ & $1.9 \pm 0.5^{e}$ & $57 \pm 15$ & $12 \pm 4.9$ \\
\hline
\end{tabular}

Data were obtained from the same control (CONT) and PRS rats of Figure $5 B$; see legend for details on treatments with CGP53432 and LY 341495 . Values are means \pm SEM of six rats per group. ${ }^{a} p<0.01$ versus all other groups; ${ }^{b} p<0.01$ versus CONT/vehicle and CONT/CGP $+\mathrm{LY}$, and $p<0.05$ versus PRS/CGP $+\mathrm{LY}^{{ }^{c}} p<0.05$ versus CONT/CGP $+\mathrm{LY}$ and PRS/vehicle; ${ }^{d} p<0.01$ versus all other groups; and ${ }^{e} p<0.05$ versus $\mathrm{CONT} /$ vehicle and $p<0.01$ versus Cont/CGP + LY. CONT, controls.

of syntaxin-1, which is involved in mechanisms of SNAREmediated membrane fusion and docking of large dense-core vesicles to the plasma membrane (Han et al., 2010). Rab3A, a member of a large family of monomeric GTP-binding proteins, regulates the trafficking of synaptic vesicles and cooperates with synapsin II in promoting the latest steps of neurotransmitter release (Sakane et al., 2006; Coleman and Bykhovskaia, 2010). PRS caused large reductions in the levels of all these proteins (except SNAP25) in the ventral hippocampus, and only reductions in the levels of syntaxin and synapsin Ia/b in the dorsal hippocampus. This profile of expression of vesicle-associated proteins fits nicely with the finding that glutamate release was reduced in the ventral hippocampus, but not in the dorsal hippocampus of PRS rats.

A potential consequence of the reduced glutamate release in the ventral hippocampus is that PRS rats become refractory to paroxysmal activity sustained by an enhanced release of glutamate. In release experiments, we used kainate as an alternative to high concentrations of $\mathrm{K}^{+}$. Kainate acting at presynaptic receptors is known to either stimulate or depress glutamate and GABA release depending on the concentrations and the hippocampal subregions (Ferkany et al., 1982; Poli et al., 1985; Chittajallu et al., 1996; Schmitz et al., 2001; Rodríguez-Moreno and Sihra, 2004). In our synaptosomal preparations, kainate caused a large release of glutamate, which was blunted in the ventral hippocampus of PRS rats. PRS rats were highly resistant to kainate-induced limbic motor seizures, which model temporal lobe epilepsy in humans (Ben-Ari and Cossart, 2000; Coulter et al., 2002). All PRS rats treated with kainate showed only mild motor signs, and none of them developed the typical secondarily generalized limbic motor seizures, which were instead seen in control rats. However, the relationship between early life stress and kainate-induced seizures is uncertain because a single episode of restraint stress on gestational day 18 enhanced kainate-induced seizures in adult gonadectomized offspring (Frye and Bayon, 1999), whereas treatment with $\beta$-methasone on gestational day 15 reduced the susceptibility to fluorothyl-induced clonic seizures, but not to kainate-induced seizures, at postnatal day 15 (Velíšek, 2011).

PRS had profound effects on glutamate release, but it failed to affect GABA release in the ventral hippocampus. The lack of changes in VGLUT1 expression and D- $\left[{ }^{3} \mathrm{H}\right]$-aspartate uptake excluded that the number of glutamatergic nerve terminals was reduced in the ventral hippocampus of PRS rats. Reductions in munc-18 and Rab3A might provide some specificity for glutamate versus GABA release. Accordingly, munc-18 regulates the size of the readily releasable vesicle pool in glutamatergic but not GABAergic terminals (Augustin et al., 1999), and Rab3A is preferentially, albeit not exclusively, expressed in glutamatergic terminals (Geppert et al., 1994). Our data suggest that PRS causes an imbalance between excitatory and inhibitory neurotransmission in the ventral hippocampus, an effect that might perturb cogni- tive functions related to stress and emotions (for review, see Bannerman et al., 2004; Engin and Treit, 2007; Fanselow and Dong, 2010). Presynaptic alterations in the glutamate/GABA balance have been associated with anxiety, depressive-like behavior, and memory impairment (Tordera et al., 2007; Garcia-Garcia et al., 2009; Chen et al., 2010). Thus, the imbalance between excitatory and inhibitory neurotransmission in the ventral hippocampus might contribute to explain the anxious/depressive-like phenotype of PRS rats (Vallée et al., 1997; Zuena et al., 2008; MorleyFletcher et al., 2011; see also present data).

Another important aspect of our study is the regional specificity in the reduction of glutamate release seen in PRS rats. Previous studies have shown that stressors of various types can have profound effects on glutamatergic transmission not only in the hippocampus but also in the prefrontal cortex, striatum, and amygdala (Fumagalli et al., 2009; Mozhui et al., 2010; Uchida et al., 2011; Farley et al., 2012; for review, see Popoli et al., 2012). For example, Fumagalli et al. (2009) have found that PRS rats challenged with a swim test in adulthood showed an attenuated phosphorylation of the NR1 subunit of NMDA receptors in the prefrontal cortex, but not in the hippocampus. In our PRS rats, glutamate release was reduced in the ventral hippocampus, but not in the dorsal hippocampus, prefrontal cortex, perirhinal cortex, striatum, or amygdala. The specificity for ventral versus dorsal hippocampus is in agreement with previous data showing that group-I mGlu receptor signaling is selectively blunted in the ventral hippocampus of PRS rats (Zuena et al., 2008). Also, the lack of changes in glutamate release in the dorsal hippocampus is in agreement with the evidence that PRS rats do not show abnormalities in spatial memory unless they are $>10$ months of age (Vallée et al., 1999), when changes in the expression of postsynaptic mGlu receptors are prominent (Van Waes et al., 2009).

To examine whether a causal relationship exists between reduction of glutamate release in the ventral hippocampus and anxiety-like behavior in PRS rats, we performed microinfusion studies with a mixture of $\mathrm{mGlu}_{2} / 3$ and $\mathrm{GABA}_{\mathrm{B}}$ receptor antagonists, which was proven to selectively enhance glutamate release in the ventral hippocampus. All animals selected for this experiment had been tested for anxiety-like behavior $\sim 2$ weeks before intrahippocampal microinfusions. Following infusions with vehicle or CGP52432 and LY341495, we designed a behavioral protocol based on two consecutive tests in the light-dark box (first) and the EPM (immediately after). This is unusual because repetitive tests for the assessment of anxiety-like behavior are generally performed with at least 1 week of interval to avoid the influence of the previous test experience (Vóikar et al., 2004; Cryan and Holmes, 2005; Paylor et al., 2006; Ballaz et al., 2007) and treatmentdependent fluctuations in behavior that may occur between two consecutive tests (Izídio et al., 2005; Ramos, 2008). We adopted the strategy of two consecutive behavioral tests to avoid the need 
to reinject CGP52432 and LY341495 in the ventral hippocampus without having knowledge of the neuroplastic changes induced by these drugs in the hippocampus. This may confound the interpretation of the EPM data (but not the interpretation of the light-dark box data) following injection of CGP52432 and LY341495 in unstressed and PRS rats. Taking into account these possible limitations, our data suggest a causal relationship between reduction of glutamate release in the ventral hippocampus and anxiety-like behavior in PRS rats. The doses of CGP52432 and LY341495 we have used ( 1 and $100 \mathrm{pg}$, respectively), did not cause nonspecific changes in motor activity in the light-dark box and EPM, and did not affect anxiety-like behavior in unstressed control rats. Thus, pharmacological enhancement of glutamate release in the ventral hippocampus could specifically reverse anxiety-like behavior in PRS rats.

The mechanisms by which PRS causes a dysfunction in glutamate release in the ventral hippocampus is unknown. PRS rats are characterized by a hyper-reactivity of the hypothalamic_-pituitary-adrenal axis, which results into a prolonged corticosterone response to stress (Maccari et al., 1995), and this might have a causal role in the dysfunction of glutamate release in the ventral hippocampus (Popoli et al., 2012). The hypothesis that high levels of corticosterone cause a long-lasting reduction in glutamate release in PRS rats warrants further investigation. We cannot exclude that changes in glutamatergic neurotransmission occurring in other brain regions contribute to the anxiety-like phenotype of PRS rats. Our data suggest that an impairment of glutamate release in the ventral hippocampus may lie at the core of the neuroplastic program induced by PRS, and strongly correlates with the development of anxiety-like behavior in these rats.

In conclusion, these findings support the "glutamatergic hypothesis" of depression and anxiety (Maeng and Zarate, 2007; Matrisciano et al., 2007; Hashimoto, 2009; Popoli et al., 2012), and suggest to extend the study of the balance between excitatory and inhibitory neurotransmission in the ventral hippocampus in other putative animal models of anxiety to develop new therapeutical strategies for stress-related disorders.

\section{References}

Augustin I, Rosenmund C, Südhof TC, Brose N (1999) Munc13-1 is essential for fusion competence of glutamatergic synaptic vesicles. Nature 400: 457-461. CrossRef Medline

Ballaz SJ, Akil H, Watson SJ (2007) Previous experience affects subsequent anxiety-like responses in rats bred for novelty seeking. Behav Neurosci 121:1113-1118. CrossRef Medline

Bannerman DM, Rawlins JN, McHugh SB, Deacon RM, Yee BK, Bast T, Zhang WN, Pothuizen HH, Feldon J (2004) Regional dissociations within the hippocampus-memory and anxiety. Neurosci Biobehav Rev 28:273-283. CrossRef Medline

Barker GR, Bashir ZI, Brown MW, Warburton EC (2006) A temporally distinct role for group I and group II metabotropic glutamate receptors in object recognition memory. Learn Mem 13:178-186.

Becker G, Kowall M (1977) Crucial role of the postnatal maternal environment in the expression of prenatal stress effects in the male rats. J Comp Physiol Psychol 91:1432-1446. CrossRef Medline

Ben-Ari Y, Cossart R (2000) Kainate, a double agent that generates seizures: two decades of progress Trends Neurosci 23:580-587.

Berg M, Bruhn T, Johansen FF, Diemer NH (1993) Kainic acid-induced seizures and brain damage in the rat: different effects of NMDA- and AMPA receptor antagonists. Pharmacol Toxicol 73:262-268. CrossRef Medline

Bonanno G, Giambelli R, Raiteri L, Tiraboschi E, Zappettini S, Musazzi L, Raiteri M, Racagni G, Popoli M (2005) Chronic antidepressants reduce depolarization-evoked glutamate release and protein interactions favoring formation of SNARE complex in hippocampus. J Neurosci 25:32703279. CrossRef Medline

Bradford MM (1976) A rapid and sensitive method for the quantitation of microgram quantities of protein utilizing the principle of protein dye binding. Anal Biochem 72:248-254. CrossRef Medline

Chalifoux JR, Carter AG (2011) GABAB receptor modulation of synaptic function. Curr Opin Neurobiol 21:339-344. CrossRef Medline

Chapman RH, Stern JM (1979) Failure of severe maternal stress or ACTH during pregnancy to affect emotionality of male rat offspring: implications of litter effects for prenatal studies. Dev Psychobiol 12:255-267. CrossRef Medline

Chen G, Henter ID, Manji HK (2010) Presynaptic glutamatergic dysfunction in bipolar disorder. Biol Psychiatry 67:1007-1009. CrossRef Medline

Chittajallu R, Vignes M, Dev KK, Barnes JM, Collingridge GL, Henley JM (1996) Regulation of glutamate release by presynaptic kainate receptors in the hippocampus. Nature 379:78-81. CrossRef Medline

Coleman WL, Bykhovskaia M (2010) Cooperative regulation of neurotransmitter release by Rab3a and synapsin II. Mol Cell Neurosci 44: 190-200. CrossRef Medline

Coulter DA, McIntyre DC, Löscher W (2002) Animal models of limbic epilepsies: what can they tell us? Brain Pathol 12:240-256. Medline

Cryan JF, Holmes A (2005) The ascent of mouse: advances in modeling human depression and anxiety. Nat Rev Drug Discov 4:775-790. CrossRef Medline

Darnaudéry M, Maccari S (2008) Epigenetic programming of the stress response in male and female rats by prenatal restraint stress. Brain Res Rev 57:571-585. CrossRef Medline

Darnaudéry M, Perez-Martin M, Bélizaire G, Maccari S, Garcia-Segura LM (2006) Insulin-like growth factor 1 reduces age-related disorders induced by prenatal stress in female rats. Neurobiol Aging 27:119-127. CrossRef Medline

Dong E, Wellman LL, Yang L, Sanford LD (2012) Effects of microinjections of Group II metabotropic glutamate agents into the amygdala on sleep. Brain Res 1452:85-95. CrossRef Medline

Dugovic C, Maccari S, Weibel L, Turek FW, Van Reeth O (1999) High corticosterone levels in prenatally stressed rats predict persistent paradoxical sleep alterations. J Neurosci 19:8656-8664. Medline

Dunkley PR, Jarvie PE, Heath JW, Kidd GJ, Rostas JA (1986) A rapid method for isolation of synaptosomes on Percoll gradients. Brain Res 372:115-129. CrossRef Medline

Epp N, Rethmeier R, Krämer L, Ungermann C (2011) Membrane dynamics and fusion at late endosomes and vacuoles-Rab regulation, multisubunit tethering complexes and SNAREs. Eur J Cell Biol 90:779-785. CrossRef Medline

Engin E, Treit D (2007) The role of hippocampus in anxiety: intracerebral infusion studies. Behav Pharmacol 18:365-374.

Fanselow MS, Dong HW (2010) Are the dorsal and ventral hippocampus functionally distinct structures? Neuron 65:7-19. CrossRef Medline

Farley S, Dumas S, El Mestikawy S, Giros B (2012) Increased expression of the Vesicular Glutamate Transporter-1 (VGLUT1) in the prefrontal cortex correlates with differential vulnerability to chronic stress in various mouse strains: effects of fluoxetine and MK-801. Neuropharmacology 62:503-517. CrossRef Medline

Ferkany JW, Zaczek R, Coyle JT (1982) Kainic acid stimulates excitatory amino acid neurotransmitter release at presynaptic receptors. Nature 298: 757-779. CrossRef Medline

Frye CA, Bayon LE (1999) Prenatal stress reduces the effectiveness of the neurosteroid 3 alpha, 5 alpha-THP to block kainic-acid-induced seizures. Dev Psychobiol 34:227-234. CrossRef Medline

Fumagalli F, Pasini M, Frasca A, Drago F, Racagni G, Riva MA (2009) Prenatal stress alters glutamatergic system responsiveness in adult rat prefrontal cortex. J Neurochem 109:1733-1744. CrossRef Medline

Garcia-Garcia AL, Elizalde N, Matrov D, Harro J, Wojcik SM, Venzala E, Ramírez MJ, Del Rio J, Tordera RM (2009) Increased vulnerability to depressive-like behavior of mice with decreased expression of VGLUT1. Biol Psychiatry 66:275-282. CrossRef Medline

Geppert M, Bolshakov VY, Siegelbaum SA, Takei K, De Camilli P, Hammer RE, Südhof TC (1994) The role of Rab3A in neurotransmitter release. Nature 369:493-497. CrossRef Medline

Greengard P, Valtorta F, Czernik AJ, Benfenati F (1993) Synaptic vesicle phosphoproteins and regulation of synaptic function. Science 259:780785. CrossRef Medline

Grillo CA, Piroli GG, Wood GE, Reznikov LR, McEwen BS, Reagan LP (2005) Immunocytochemical analysis of synaptic proteins provides new 
insights into diabetes-mediated plasticity in the rat hippocampus. Neuroscience 136:477-486. CrossRef Medline

Han GA, Malintan NT, Collins BM, Meunier FA, Sugita S (2010) Munc18-1 as a key regulator of neurosecretion. J Neurochem 115:1-10. CrossRef Medline

Hashimoto K (2009) Emerging role of glutamate in the pathophysiology of major depressive disorder. Brain Res Rev 61:105-123. CrossRef Medline

Hinz B, Becher A, Mitter D, Schulze K, Heinemann U, Draguhn A, AhnertHilger G (2001) Activity-dependent changes of the presynaptic synaptophysin-synaptobrevin complex in adult rat brain. Eur J Cell Biol 80:615-619. CrossRef Medline

Hussain S, Davanger S (2011) The discovery of the soluble N-ethylmaleimidesensitive factor attachment protein receptor complex and the molecular regulation of synaptic vesicle transmitter release: the 2010 Kavli Prize in neuroscience. Neuroscience 190:12-20. CrossRef Medline

Izídio GS, Lopes DM, Spricigo L Jr, Ramos A (2005) Common variations in the pretest environment influence genotypic comparisons in models of anxiety. Genes Brain Behav 4:412-419. CrossRef Medline

Jackson GL, Kuehl D (2002) The GABA(B) antagonist CGP 52432 attenuates the stimulatory effect of the GABA(B) agonist SKF 97541 on luteinizing hormone secretion in the male sheep. Exp Biol Med 227:315-320.

Joëls M (2009) Stress, the hippocampus, and epilepsy. Epilepsia 50:586597. CrossRef Medline

Krishnan V, Nestler EJ (2008) The molecular neurobiology of depression. Nature 455:894-902. CrossRef Medline

Krishnan V, Nestler EJ (2010) Linking molecules to mood: new insight into the biology of depression. Am J Psychiatry 167:1305-1320. CrossRef Medline

Laloux C, Mairesse J, Van Camp G, Giovine A, Branchi I, Bouret S, MorleyFletcher S, Bergonzelli G, Malagodi M, Gradini R, Nicoletti F, Darnaudéry M, Maccari S (2012) Anxiety-like behavior and associated neurochemical and endocrinological alterations in male pups exposed to prenatal stress. Psychoneuroendocrinology 37:1646-1658. CrossRef Medline

Lanza M, Fassio A, Gemignani A, Bonanno G, Raiteri M (1993) CGP 52432: a novel potent and selective $\mathrm{GABAB}$ autoreceptor antagonist in rat cerebral cortex. Eur J Pharmacol 237:191-195. CrossRef Medline

Li DP, Pan HL (2007) Role of gamma-aminobutyric acid (GABA)A and GABAB receptors in paraventricular nucleus in control of sympathetic vasomotor tone in hypertension. J Pharmacol Exp Ther 320:615-626. Medline

Lupien SJ, McEwen BS, Gunnar MR, Heim C (2009) Effects of stress throughout the lifespan on the brain, behavior and cognition. Nat Rev Neurosci 10:434-445. CrossRef Medline

Maccari S, Morley-Fletcher S (2007) Effects of prenatal restraint stress on the hypothalamus-pituitary-adrenal axis and related behavioral and neurobiological alterations. Psychoneuroendocrinology 32 [Suppl 1]:S10S15.19.

Maccari S, Piazza PV, Kabbaj M, Barbazanges A, Simon H, Le Moal M (1995) Adoption reverses the long-term impairment in glucocorticoid feedback induced by prenatal stress. J Neurosci 15:110-116. Medline

Maeng S, Zarate CA Jr (2007) The role of glutamate in mood disorders: results from the ketamine in major depression study and the presumed cellular mechanism underlying its antidepressant effects. Curr Psychiatry Rep 9:467-474. CrossRef Medline

Mairesse J, Silletti V, Laloux C, Zuena AR, Giovine A, Consolazione M, van Camp G, Malagodi M, Gaetani S, Cianci S, Catalani A, Mennuni G, Mazzetta A, van Reeth O, Gabriel C, Mocaër E, Nicoletti F, MorleyFletcher S, Maccari S (2012a) Chronic agomelatine treatment corrects the abnormalities in the circadian rhythm of motor activity and sleep/ wake cycle induced by prenatal restraint stress in adult rats. Int J Neuropsychopharmacol 6:1-16. Medline

Mairesse J, Vercoutter-Edouart AS, Marrocco J, Zuena AR, Giovine A, Nicoletti F, Michalski JC, Maccari S, Morley-Fletcher S (2012b) Proteomic characterization in the hippocampus of prenatally stressed rats. J Proteomics 75:1764-1770. CrossRef Medline

Martisova E, Solas M, Horrillo I, Ortega JE, Meana JJ, Tordera RM, Ramírez MJ (2012) Long lasting effects of early-life stress on glutamatergic/ GABAergic circuitry in the rat hippocampus. Neuropharmacology 62: 1944-1953. CrossRef Medline

Matrisciano F, Panaccione I, Zusso M, Giusti P, Tatarelli R, Iacovelli L, Mathé AA, Gruber SH, Nicoletti F, Girardi P (2007) Group-II metabotropic glutamate receptor ligands as adjunctive drugs in the treatment of depres- sion: a new strategy to shorten the latency of antidepressant medication? Mol Psychiatry 12:704-706. CrossRef Medline

McEwen BS (2012) The ever-changing brain: cellular and molecular mechanisms for the effects of stressful experiences. Dev Neurobiol 72:878-890. CrossRef Medline

Meaney MJ, Szyf M, Seckl JR (2007) Epigenetic mechanisms of perinatal programming of hypothalamic-pituitary-adrenal function and health. Trends Mol Med 13:269-277. CrossRef Medline

Moghaddam B (2002) Stress activation of glutamate neurotransmission in the prefrontal cortex: implications for dopamine-associated psychiatric disorders. Biol Psychiatry 51:775-787. CrossRef Medline

Morley-Fletcher S, Darnaudery M, Koehl M, Casolini P, Van Reeth O, Maccari S (2003) Prenatal stress in rats predicts immobility behavior in the forced swim test. Effects of a chronic treatment with tianeptine. Brain Res 989:246-251. CrossRef Medline

Morley-Fletcher S, Darnaudéry M, Mocaer E, Froger N, Lanfumey L, Laviola G, Casolini P, Zuena AR, Marzano L, Hamon M, Maccari S (2004) Chronic treatment with imipramine reverses immobility behavior, hippocampal corticosteroid receptors and cortical 5- $\mathrm{HT}(1 \mathrm{~A})$ receptor mRNA in prenatally stressed rats. Neuropharmacology 47:841-847. CrossRef Medline

Morley-Fletcher S, Mairesse J, Soumier A, Banasr M, Fagioli F, Gabriel C, Mocaer E, Daszuta A, McEwen B, Nicoletti F, Maccari S (2011) Chronic agomelatine treatment corrects behavioral, cellular, and biochemical abnormalities induced by prenatal stress in rats. Psychopharmacology 217 301-313. CrossRef Medline

Mozhui K, Karlsson RM, Kash TL, Ihne J, Norcross M, Patel S, Farrell MR, Hill EE, Graybeal C, Martin KP, Camp M, Fitzgerald PJ, Ciobanu DC, Sprengel R, Mishina M, Wellman CL, Winder DG, Williams RW, Holmes A (2010) Strain differences in stress responsivity are associated with divergent amygdala gene expression and glutamate-mediated neuronal excitability. J Neurosci 30:5357-5367. CrossRef Medline

Musazzi L, Milanese M, Farisello P, Zappettini S, Tardito D, Barbiero VS, Bonifacino T, Mallei A, Baldelli P, Racagni G, Raiteri M, Benfenati F, Bonanno G, Popoli M (2010) Acute stress increases depolarizationevoked glutamate release in the rat prefrontal/frontal cortex: the dampening action of antidepressants. PLoS One 5:e8566. CrossRef Medline

Nicoletti F, Bockaert J, Collingridge GL, Conn PJ, Ferraguti F, Schoepp DD, Wroblewski JT, Pin JP (2011) Metabotropic glutamate receptors: from the workbench to the bedside. Neuropharmacology 60:1017-1041. CrossRef Medline

Ongür D, Jensen JE, Prescot AP, Stork C, Lundy M, Cohen BM, Renshaw PF (2008) Abnormal glutamatergic neurotransmission and neuronal-glial interactions in acute mania. Biol Psychiatry 64:718-726. CrossRef Medline

Paxinos G, Watson C (2007) The Rat brain in stereotaxic coordinates, Ed 6 . London: Academic.

Paylor R, Spencer CM, Yuva-Paylor LA, Pieke-Dahl S (2006) The use of behavioral test batteries, II: effect of test interval. Physiol Behav 87:95102. CrossRef Medline

Pellow S, Chopin P, File SE, Briley M (1985) Validation of open:closed arm entries in an elevated plus-maze as a measure of anxiety in the rat. J Neurosci Methods 14:149-167. CrossRef Medline

Poli A, Contestabile A, Migani P, Rossi L, Rondelli C, Virgili M, Bissoli R, Barnabei O (1985) Kainic acid differentially affects the synaptosomal release of endogenous and exogenous amino acidic neurotransmitters. J Neurochem 45:1677-1686. CrossRef Medline

Popoli M, Yan Z, McEwen BS, Sanacora G (2012) The stressed synapse: the impact of stress and glucocorticoids on glutamate transmission. Nat Rev Neurosci 13:22-37. Medline

Racine RJ (1972) Modification of seizure activity by electrical stimulation. II. Motor seizure. Electroencephalogr Clin Neurophysiol 32:281-294. Medline

Raiteri L, Raiteri M (2000) Synaptosomes still viable after 25 years of superfusion. Neurochem Res 25:1265-1274. CrossRef Medline

Raiteri M, Angelini F, Levi G (1974) A simple apparatus for studying the release of neurotransmitters from synaptosomes. Eur J Pharmacol 25: 411-414. CrossRef Medline

Ramos A (2008) Animal models of anxiety: do I need multiple tests? Trends Pharmacol Sci 29:493-498. CrossRef Medline

Robertson DA, Beattie JE, Reid IC, Balfour DJ (2005) Regulation of corti- 
costeroid receptors in the rat brain: the role of serotonin and stress. Eur J Neurosci 21:1511-1520. CrossRef Medline

Rodríguez-Moreno A, Sihra TS (2004) Presynaptic kainate receptor facilitation of glutamate release involves protein kinase $\mathrm{A}$ in the rat hippocampus. J Physiol 557:733-745. CrossRef Medline

Sakane A, Manabe S, Ishizaki H, Tanaka-Okamoto M, Kiyokage E, Toida K, Yoshida T, Miyoshi J, Kamiya H, Takai Y, Sasaki T (2006) Rab3 GTPaseactivating protein regulates synaptic transmission and plasticity through the inactivation of Rab3. Proc Natl Acad Sci U S A 103:10029-10034. CrossRef Medline

Schmitz D, Mellor J, Frerking M, Nicoll RA (2001) Presynaptic kainate receptors at hippocampal mossy fiber synapses. Proc Natl Acad Sci U S A 98:11003-11008. CrossRef Medline

Schoepp DD, Jane DE, Monn JA (1999) Pharmacological agents acting at subtypes of metabotropic glutamate receptors. Neuropharmacology 38: 1431-1476. CrossRef Medline

Sharma AK, Reams RY, Jordan WH, Miller MA, Thacker HL, Snyder PW (2007) Mesial temporal lobe epilepsy: pathogenesis, induced rodent models and lesions. Toxicol Pathol 35:984-999. CrossRef Medline

Sperk G, Lassmann H, Baran H, Kish SJ, Seitelberger F, Hornykiewicz O (1983) Kainic acid induced seizures: neurochemical and histopathological changes. Neuroscience 10:1301-1315. CrossRef Medline

Thome J, Pesold B, Baader M, Hu M, Gewirtz JC, Duman RS, Henn FA (2001) Stress differentially regulates synaptophysin and synaptotagmin expression in hippocampus. Biol Psychiatry 50:809-812. CrossRef Medline

Tordera RM, Totterdell S, Wojcik SM, Brose N, Elizalde N, Lasheras B, Del Rio J (2007) Enhanced anxiety, depressive-like behavior and impaired recognition memory in mice with reduced expression of the vesicular glutamate transporter 1 (VGLUT1). Eur J Neurosci 25:281-290. CrossRef Medline

Uchida S, Hara K, Kobayashi A, Otsuki K, Yamagata H, Hobara T, Suzuki T, Miyata N, Watanabe Y (2011) Epigenetic status of Gdnf in the ventral striatum determines susceptibility and adaptation to daily stressful events. Neuron 69:359-372. CrossRef Medline

Vallée M, Mayo W, Dellu F, Le Moal M, Simon H, Maccari S (1997) Prenatal stress induces high anxiety and postnatal handling induces low anxiety in adult offspring: correlation with stress-induced corticosterone secretion. J Neurosci 17:2626-2636. Medline

Vallée M, MacCari S, Dellu F, Simon H, Le Moal M, Mayo W (1999) Longterm effects of prenatal stress and postnatal handling on age-related glucocorticoid secretion and cognitive performance: a longitudinal study in the rat. Eur J Neurosci 11:2906-2916. CrossRef Medline

Valtorta F, Benfenati F, Greengard P (1992) Structure and function of the synapsins. J Biol Chem 267:7195-7198. Medline

Van Waes V, Enache M, Zuena A, Mairesse J, Nicoletti F, Vinner E, Lhermitte M, Maccari S, Darnaudéry M (2009) Ethanol attenuates spatial memory deficits and increases mGlula receptor expression in the hippocampus of rats exposed to prenatal stress. Alcohol Clin Exp Res 33:1346-1354. CrossRef Medline

Van Waes V, Darnaudéry M, Marrocco J, Gruber SH, Talavera E, Mairesse J, Van Camp G, Casolla B, Nicoletti F, Mathé AA, Maccari S, MorleyFletcher S (2011) Impact of early life stress on alcohol consumption and on the short- and long-term responses to alcohol in adolescent female rats. Behav Brain Res 221:43-49. CrossRef Medline

Velíšek L (2011) Prenatal corticosteroid exposure alters early developmental seizures and behavior. Epilepsy Res 95:9-19. CrossRef Medline

Vǒikar V, Vasar E, Rauvala H (2004) Behavioral alterations induced by repeated testing o in C57BL/6J and 129S2/SV mice: implications for phenotyping screens. Genes Brain Behav 3:27-38. CrossRef Medline

Walter AM, Groffen AJ, Sørensen JB, Verhage M (2011) Multiple Ca2+ sensors in secretion: teammates, competitors or autocrats? Trends Neurosci 34:487-497. CrossRef Medline

Yamamoto BK, Reagan LP (2006) The glutamatergic system in neuronal plasticity and vulnerability in mood disorders. Neuropsychiatr Dis Treat 2:7-14.

Zuena AR, Mairesse J, Casolini P, Cinque C, Alem à GS, Morley-Fletcher S, Chiodi V, Spagnoli LG, Gradini R, Catalani A, Nicoletti F, Maccari S (2008) Prenatal restraint stress generates two distinct behavioral and neurochemical profiles in male and female rats. PLoS One 3:e2170. CrossRef Medline 